Discussion Paper No. 16-081

Public ICT Investment in Reaction to the Economic Crisis A Case Study on Measuring IT-related Intangibles in the Public Sector

Marianne Saam, Laura Weinhardt, and Lukas Trottner

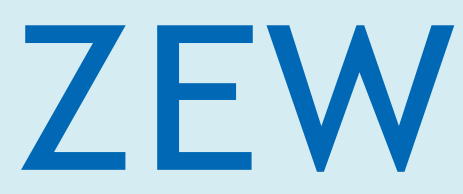

Zentrum für Europäische Wirtschaftsforschung $\mathrm{GmbH}$ Centre for European Economic Research 


\title{
Discussion Paper No. 16-081 \\ Public ICT Investment in Reaction to the Economic Crisis - A Case Study on Measuring IT-related Intangibles in the Public Sector
}

\author{
Marianne Saam, Laura Weinhardt, \\ and Lukas Trottner
}

Download this ZEW Discussion Paper from our ftp server:

http://ftp.zew.de/pub/zew-docs/dp/dp16081.pdf

Die Discussion Papers dienen einer möglichst schnellen Verbreitung von neueren Forschungsarbeiten des ZEW. Die Beiträge liegen in alleiniger Verantwortung der Autoren und stellen nicht notwendigerweise die Meinung des ZEW dar. 


\title{
Public ICT Investment in Reaction to the Economic Crisis - A Case Study on Measuring IT-related Intangibles in the Public Sector
}

\author{
Marianne Saam (ZEW Mannheim) ${ }^{*}$, Laura Weinhardt (Sopra Steria \\ $\mathrm{GmbH})^{\dagger}$, Lukas Trottner (ZEW Mannheim and University of \\ Mannheim)
}

November 2016

\begin{abstract}
In this paper, we (1) analyse the German public IT-spending programme 2009-11 adopted after the crisis in terms of its tangible vs. intangible asset creation, (2) consider this relatively well-described programme as a use case for categorising ITrelated intangibles in government beyond software (including e.g., IT-training, innovation in e-services), (3) investigate how to form insightful aggregates of intangible IT-related investment from project level data and, in comparison, from the regular public budget in Germany. Based on project descriptions, we find out that half of the spending was on IT security-related projects. According to our estimations based on quantitative information, qualitative information and approximations, about half of the total spending was on intangibles, of which again about half went into software and a quarter into consulting. As a new output-based category for some assets created in the programme, we propose the category "concepts".
\end{abstract}

\footnotetext{
*Corresponding author: saam@zew.de. This research has received funding from the European Union's Seventh Framework Programme for research, technological development and demonstration under grant agreement no: 612774 (SPINTAN Project: Smart Public Intangibles). The authors gratefully acknowledge helpful suggestions from the SPINTAN workshop in London in October 2014 and from the SPINTAN mid-term conference in Valencia in September 2015. This paper is also published as SPINTAN deliverable D5.5.

${ }^{\dagger}$ Laura Weinhardt worked on the project during an internship at ZEW. Part of this paper draws on her Master thesis at Goethe University Frankfurt.
} 


\section{Table of Content}

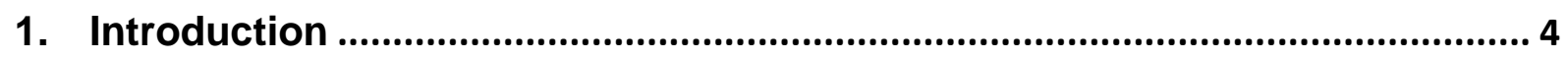

2. The German IT investment programme 2009-11 in the international context of stimulus packages .............................................................................................. 5

3. Database on the German IT investment programme 2009-11 .......................... 7

3.1. The Structure of the German Federal IT Investment Programme ................... 7

3.2. The Database on the IT Investment Programme............................................ 9

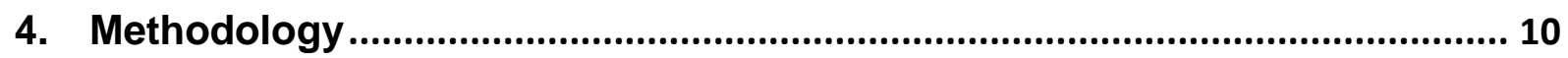

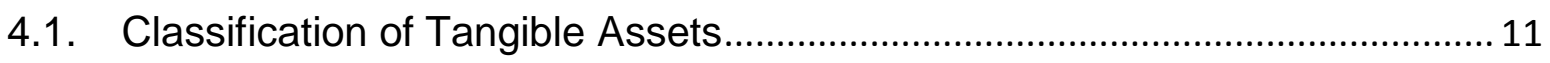

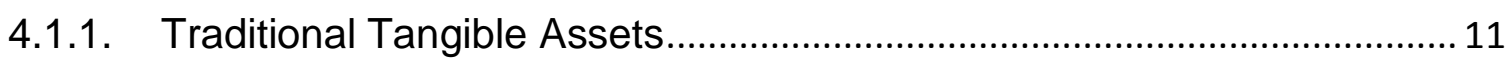

4.1.2. Hardware

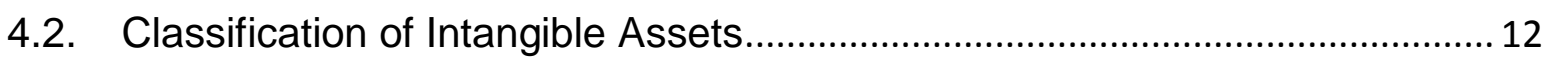

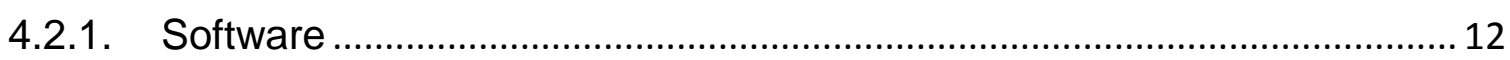

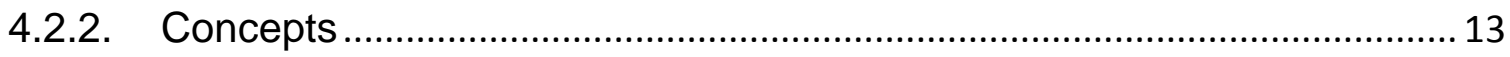

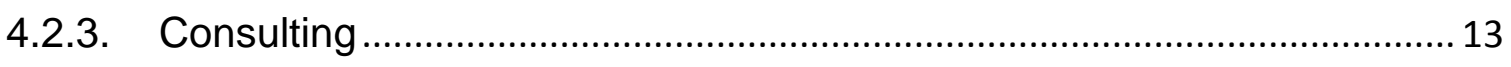

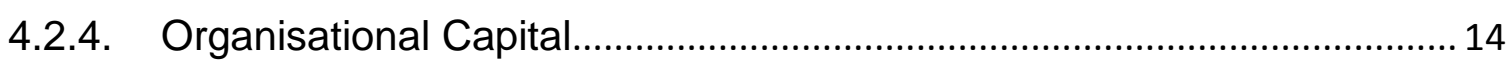

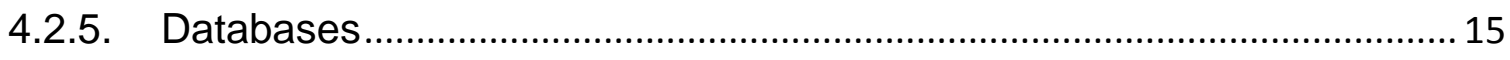

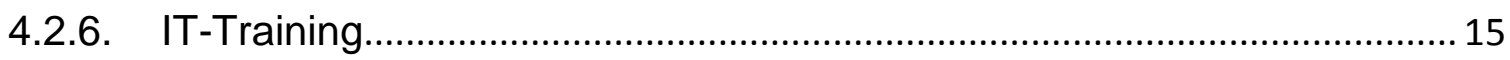

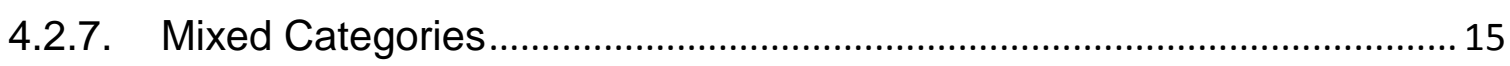

4.3. Classification of Mixed Projects ................................................................. 17

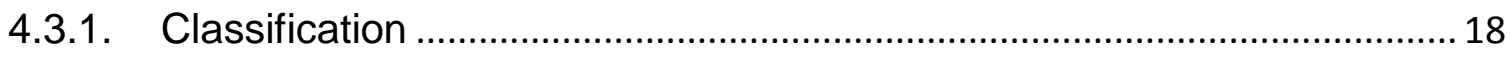

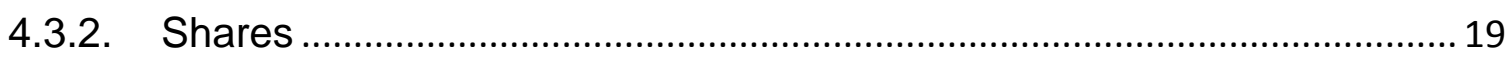

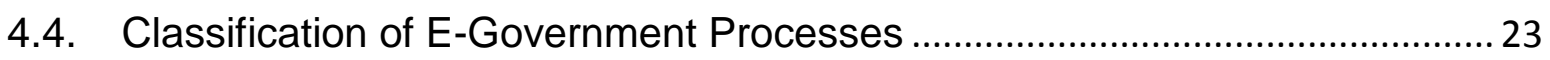

5. Results on Intangible Investment and E-Government..................................... 29

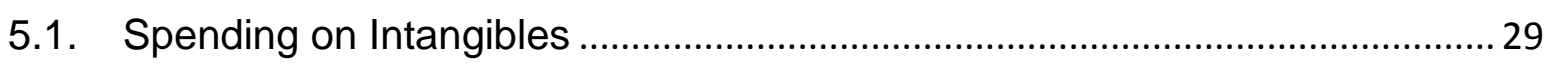

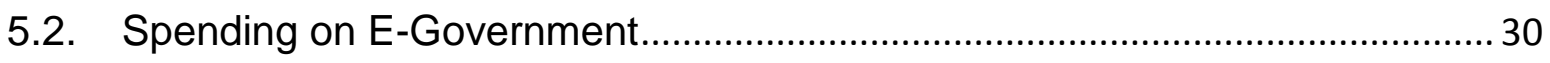

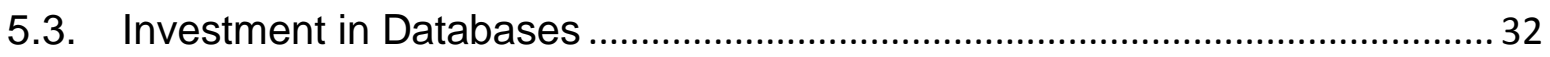

6. Comparison of Results to Regular IT Spending at the Federal Level .......... 33

6.1. Classification of IT Spending in the German Federal Budget........................... 33

6.2. IT Spending and IT Investment at the Federal Level 2010 ............................. 35

6.3. Comparison with the Results from the Anti-Crisis Programme ........................37

7. Conclusion ............................................................................................................... 37 


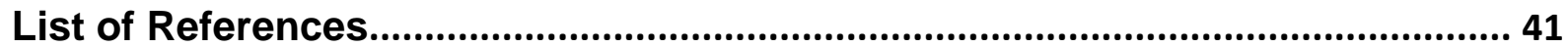

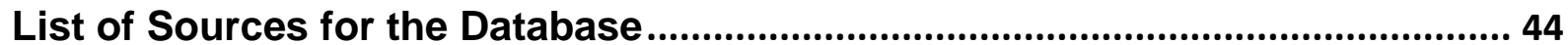




\section{Introduction}

Which kind of government spending was undertaken in reaction to the economic crisis in 2007-2008 and how did this affect the creation of intangible assets in the public sector? We address this question based on a particular use case, the German IT spending programme 2009-2011 at the level of the Federal Government. We thus focus on IT-related intangibles as a particular subset of intangibles. They include IT assets, mainly software, but also other intangible assets that are created to complement IT assets, e.g. investment in new organisational structures or organisation-specific training.

We follow the well-established conceptual framework by Corrado et al. (2005) that classifies as intangible investment those activities thought to increase future production and consumption without the creation of a tangible asset. Several papers, among them Corrado et al. (2009) and Baldwin et al. (2012), come to the conclusion that the remarkable increase in labour productivity growth observed after 1995 for the United States and other developed countries can be partly explained through the inclusion of investment in intangible assets into the analysis. However, as criticised by Corrado et al. (2014), national accounts still lack sophisticated information on intangibles. This is even truer for the public sector (Barabas et al., 2011).

One of the issues with analysing investment of the public sector is that the data provided do often not include information on the products produced and purchased (Corrado et al., 2014). Approaches to classify and to measure investment in intangible assets are thus so far mostly restricted to the business sector. This is the starting point for our research in the context of the SPINTAN project. By means of an IT investment programme conducted by the German Government, we apply the classification scheme commonly applied to the business sector to public IT investment in intangible assets.

There is some research on IT in the public sector that does, however, not focus on measurement of intangible assets in a manner consistent with national accounts. Alencar et al. (2013) analyse public sector IT investment and propose a method to evaluate IT projects in the public sector. They take into account the fact that IT projects can be divided into various subprojects of smaller size and present a method on how to maximise the appropriation of intangible benefits stemming from IT investments. In a subsequent paper, Fernandes et al. (2014) build upon their model and present a method on how to identify the best order of implementation for the several subprojects of an IT project. They specifically concentrate on balancing the expenses on the IT project and the intangible benefits it provides while aiming at improving management efficiency.

Other studies rather focus on the lack of availability concerning public data. As Bunget et al. (2014) claim, one of the greatest obstacles to research on this topic is given by the reluctance of the public sector to disclose the relevant data. Oulasvirta 
(2012) further investigates possible reasons for the unwillingness of the public sector to comply with international accounting standards.

Focusing more on public intangible investments, Jarboe (2013) investigates the importance of public investments into knowledge-based and intangible assets by referring to the budget of the U.S. Government. He provides a list of the intangible assets included in the budget for the fiscal year 2014. Similar to business sector intangible investment, it includes investment in the classes "Information and Intellectual Property", "Individual Human Capital", "Social Capital (Alliances \& Networks)" and "Brands and Marketing - Reputation".

With the possibilities of ever more advanced information technology, the processes and services of the government have changed. Fernandes et al. (2015) exploit the strong link between intangible investment and e-government investment to provide a method which can be used to evaluate tangible and intangible benefits generated by e-government projects while taking their dynamic nature into account.

\section{The German IT investment programme 2009-11 in the international context of stimulus packages}

The "Konjunkturpaket II" ${ }^{1}$ was a package of measures aimed at stimulating the German economy after the deep impact of the global financial crisis. It had a budget of 50 billion Euros of which around 17 were to be spent on investment. Investment at the federal level had a budget of $€ 4$ billion; the remaining investment was planned at the regional and communal level. It proofed difficult to spend the entire investment budget during the intended time period (Barabas et al., 2011). The IT investment programme within the Federal Government ${ }^{2}$ provided investments amounting to roughly $€ 500$ million within the "Konjunkturpaket II". Another IT-related target of "Konjunkturpaket II" was broadband infrastructure. Due to the regional administration of the measures, the total spent on IT beyond the programme within Federal Government is difficult to trace back. But the investment budget of "Konjunkturpaket II" was targeted for more than half at educational infrastructure. Other building infrastructure and transport infrastructure constituted further areas of spending. In 2009, the OECD reports an estimate of $€ 150$ million intended to be spent on broadband in German stimulus measures (OECD, 2009).

In reaction to the economic crisis, many countries included IT spending in their recovery programs. In the US, the "American Recovery and Reinvestment Act"3

\footnotetext{
${ }^{1}$ Among others the recovery package "Konjunkturpaket II", aimed at relieving private households as well as the introduction of the car scrapping premium. For more information see http://dipbt.bundestag.de/extrakt/ba/WP16/179/17946.html. [22.11.2016]

${ }^{2}$ For more information see the website of the programme http://www.cio.bund.de/Web/DE/Strategische-Themen/ITInvestitionsprogramm/it investitionsprogramm node.html. [22.11.2016] ${ }^{3}$ Available from: https://www.gpo.gov/fdsys/pkg/PLAW-111publ5/html/PLAW-111publ5.htm. [22.11.2016]
} 
earmarked among others investments in smart grid technologies ( $\$ 4.5$ billion) and broadband networks ( $\$ 7.2$ billion) as investment opportunities.

Investing in the modernisation and expansion of the broadband network as part of general investments in infrastructure is a measure that could be observed in many other countries as well. Although some national broadband plans were not directly designated as part of a more general recovery program, it is remarkable that most of these programs were called into action in a two-year period following the outbreak of the crisis.

For instance, the United Kingdom published its "Digital Britain Final Report" in June $2009,{ }^{4}$ which lines out a national strategy aiming to establish the UK as one of the leaders of the global digital economy. Essential to this strategy was providing universal access to broadband internet connection with a download speed of least 2 Mbps until 2012 and giving 95 percent of the UK population access to broadband speed of at least $24 \mathrm{Mbps}$ (next-generation access) by 2017. To achieve this, the government designated $£ 530$ million to connect rural communities and stimulate commercial investment as well as $£ 250$ million to provide next-generation access, initially through a $£ 10$ million competitive fund.

South Korea introduced plans to upgrade the wired networks from guaranteed speeds of $100 \mathrm{Mbps}$ to $1 \mathrm{Gbps}$ and mobile networks to speeds of $10 \mathrm{Mbps}$ providing 1.3 trillion won of government funds as part of the estimated costs of 34.1 trillion won (Dwivedi, 2011).

In Germany, a national broadband strategy was published in February $2009^{5}$ following the adoption of the "Konjunkturpaket II" $\left(2^{\text {nd }}\right.$ stimulus package), which earmarked funds for the modernization and expansion of the German broadband network. The government set the goal to provide universal access to broadband internet with speeds of at least $1 \mathrm{Mbps}$ by the end of 2010 and to provide high speed internet access (at least $50 \mathrm{Mbps}$ ) to 75 percent of the citizens by 2014. Government grants were among others designated at the expansion of the broadband network to rural regions in order to compensate the margin erosion between rural and urbanised areas. As noted above, an estimated investment amount in broadband projects of $€$ 150 million was made available by the program "Konjunkturpaket II" directly. Compared to recovery programmes in other countries, the share of broadband investment in "Konjunkturpaket II" looks quite low.

When it comes to investments that are made within the public sector administration as part of stimulus packages, information is less detailed than on broadband for many countries.

\footnotetext{
${ }^{4}$ Available from: https://www.gov.uk/government/uploads/system/uploads/attachment data/file/228844/7650.pdf. [22.11.2016].

${ }^{5}$ Available from: http://www.bmwi.de/Dateien/BBA/PDF/breitbandstrategie-derbundesregierung, property=pdf, bereich=bmwi,sprache=de, rwb=true.pdf. [22.11.2016].
} 
The US "American Recovery and Reinvestment Act" spent around \$ 300 million on upgrading the IT infrastructure at the federal level. This involved building a second, redundant data centre for the Bureau of Information Resources Management in Denver for around $\$ 70$ million and the award for a closely related contract of $\$ 65$ million. Other, smaller contracts purchased further services associated with the installation of the data centre. Another $\$ 60$ million were spent on upgrading IT security. Typical projects with a budget between $\$ 1$ and $\$ 10$ million concerned the consolidation of data centres, improving recording and tracking in the systems of the passport and visa services, the provision of various items of computer equipment and software. The supplier of each set of goods or services is described using the official US industry classification, which could facilitate the analysis of the assets created. ${ }^{6}$ Contrary to the German federal spending programme, which will be analysed in detail in this paper, the American programme seems to have been more centralised and to have contained less distinct thematic priorities (such as Green IT or innovation). To take the example of a further major OECD country, France invested $€ 800$ million in IT as part of its stimulus package adopted in 2009. Most of the investment was for fibre optic broadband ( $€ 750$ million), smaller sums were targeted at the development of 'serious games' ( $€ 30$ million) and at projects developing Web 2.0 platforms ( $€ 20$ million). Within the already existing plan "Digital France 2012" some goals were targeted at e-government, but specific budget numbers allocated for attaining these goals were not published.

The German Federal IT Investment Programme had several targets. It intended to consolidate and modernise the IT infrastructure at the central government and to make it more secure. Moreover, it aimed at the development of a more citizenoriented and eco-friendly federal administration as well as at sustainably strengthening the German ICT economy. Ultimately, it was designed to secure and create new jobs in the ICT sector. In total, around 371 individual measures have been carried out in the scope of the programme with more than 800 companies involved.

\section{Database on the German IT investment programme 2009-11}

\subsection{The Structure of the German Federal IT Investment Programme}

In this paper, we use project-level data from the German investment programme at the Federal Government level to apply a classification of intangible investment on it and to evaluate the shares spent on e-government and on other purposes. What

\footnotetext{
${ }^{6}$ Information available from: http://www.census.gov/eos/www/naics/. [22.11.2016]. . The official document describing the American Recovery and Reinvestment Act is found on http://frwebgate.access.gpo.gov/cgi-bin/getdoc.cgi?dbname=111 cong bills\&docid=f:h1enr.pdf. [22.11.2016].
} 
distinguishes our approach from other research on intangibles is to focus on ITrelated intangibles within government only.

The programme was built upon four pillars which represent different areas of investment (see Table 1).

Table 1: IT Investment Programme - Sectors

\begin{tabular}{|l|l|l|l|}
\hline \multicolumn{1}{|c|}{ A } & \multicolumn{1}{|c|}{ B } & \multicolumn{1}{c|}{ C } & \multicolumn{1}{c|}{ D } \\
\hline IT & $\begin{array}{l}\text { Improving the IT } \\
\text { Security } \\
\text { organisation of } \\
\text { the } \quad \begin{array}{l}\text { Green } \\
\text { government }\end{array}\end{array}$ & $\begin{array}{l}\text { Sustainability } \\
\text { and Innovation }\end{array}$ \\
\hline
\end{tabular}

The programme was additionally subdivided into 15 main blocks of activities as well as in interdepartmental and department-specific measures. The interdepartmental measures were realised under the control of the Federal Government's IT management. The department-specific measures were carried out in a decentralised way. The central programme management was performed by the project group IT investment programme (PG Invest). Tables 2 and 3 present the interdepartmental and department-specific measures.

Table 2: Interdepartmental Measures

\begin{tabular}{|c|l|}
\hline A1: & $\begin{array}{l}\text { Purchase of goods and services in order to } \\
\text { increase the IT security of the public } \\
\text { administration }\end{array}$ \\
\hline A2: & $\begin{array}{l}\text { Ensuring IT security of the public administrations' } \\
\text { network infrastructure }\end{array}$ \\
\hline A3: & $\begin{array}{l}\text { Strengthening the property networks of the } \\
\text { Federal Government }\end{array}$ \\
\hline A4: & $\begin{array}{l}\text { Federal Government grant for an IT security } \\
\text { package for citizens (card reader, security } \\
\text { software, qualified electronical signature) }\end{array}$ \\
\hline B1: & $\begin{array}{l}\text { Expansion of the OSS competence centre and of } \\
\text { the knowledge and document management } \\
\text { systems }\end{array}$ \\
\hline B2: & $\begin{array}{l}\text { Upgrade the capacities of major IT project } \\
\text { management }\end{array}$ \\
\hline C1: & $\begin{array}{l}\text { Development of a competence centre and a } \\
\text { model computer centre }\end{array}$ \\
\hline D1: & $\begin{array}{l}\text { Provision of IT infrastructure components to foster } \\
\text { the usage of electronic authentication and } \\
\text { signature processes in commerce and } \\
\text { administration by means of the electronic identity } \\
\text { card }\end{array}$ \\
\hline D2: & $\begin{array}{l}\text { Development of e-government infrastructure } \\
\text { services within the scope of projects at } \\
\text { federal/state level, particularly concerning } \\
\text { "Deutschland-Online" }\end{array}$ \\
\hline
\end{tabular}




\begin{tabular}{|c|l|}
\hline A5: & $\begin{array}{l}\text { Procurement of IT security services and products } \\
\text { by public authorities }\end{array}$ \\
\hline B3: & $\begin{array}{l}\text { Improving the offer of IT services in high- } \\
\text { performing IT service centres }\end{array}$ \\
\hline C2: & Federal Investment Programme Green IT \\
\hline D3: & $\begin{array}{l}\text { "Digitales Deutschland - Einfach Online } \\
\text { beteiligen" }\end{array}$ \\
\hline D4: & $\begin{array}{l}\text { Reduction of bureaucratic costs by means of } \\
\text { electronic process chains linking commerce and } \\
\text { administration }\end{array}$ \\
\hline D5: & Open Source Software Projects \\
\hline C1: & $\begin{array}{l}\text { Development of a competence centre and a } \\
\text { model computer centre }\end{array}$ \\
\hline D1: & $\begin{array}{l}\text { Provision of IT infrastructure components to foster } \\
\text { the usage of electronic authentication and } \\
\text { signature processes in commerce and } \\
\text { administration by the means of the electronic } \\
\text { identity card }\end{array}$ \\
\hline D2: & $\begin{array}{l}\text { Development of e-government infrastructure } \\
\text { services within the scope of projects at } \\
\text { federal/state level, particularly concerning } \\
\text { Deutschland-Online }\end{array}$ \\
\hline
\end{tabular}

The selection of measures was based on specific criteria. Those included the shortand long-term efficacy of the measures, the sustainability and the overall costeffectiveness as well as the administrative burden and the innovative strength of the measures.

The German programme shares with the US programme a focus on IT security. Investment in data centres is less massive than in the US.

\subsection{The Database on the IT Investment Programme}

To build up the database, ${ }^{7}$ it was first of all necessary to find documentation on the projects. We extracted the information from two separate PDF-documents, which both included a table of the projects. We found the first document "Übersicht der zugesagten Finanzmittel im Rahmen des IT-Investitionsprogramms - beendete Maßnahmen" on the programme's website. ${ }^{8}$ It includes solely information on the thematic block the project is associated with, the department being in charge of the project, the title of the project, the amount of money invested as well as the department or institution where the project should be carried out. We found a more elaborate version of the same document on the website presenting the enactments of

\footnotetext{
${ }^{7}$ The database is provided in form of an electronical spread-sheet and is available upon request from the authors.

${ }^{8}$ http://www.cio.bund.de/SharedDocs/Publikationen/DE/Strategische-

Themen/liste beendete massnahmen download.pdf;jsessionid=A7196F58C1F6D7A65A7A32FECB3549F6.2 ci d334? blob=publicationFile. [22.11.2016].
} 
the "IT-Rat". ${ }^{9}$ It includes an additional short description of the project's measures. We are hence given mostly qualitative information on the projects.

We then extracted the data into a spreadsheet and separated it according to the four blocks. Moreover, we created severable variables for the analysis that are described in the following section. The database allows us to gauge how much of the funds were actually invested into intangible assets and which intangible assets received which share. Moreover, we aim at providing figures on the amount invested into different categories of e-government projects. In order to do so we need to approach this mostly qualitative data with a specific methodology.

\section{Methodology}

The classification and categorisation of the projects is based on the conceptual framework developed by Corrado et al. $(2005,2009)$ and the empirical information provided in different online sources. The individual criteria for the classifications and categories have grown out of the projects themselves. We went through each project individually and tried to gather as much information as possible on it. The examples provided for each category are hand-picked and should demonstrate the reasoning behind the criteria. At this stage we already want to point out that due to the quality of the data, we needed to make certain assumptions for many projects in order to be able to categorise them. These will be explained for each category.

As Corrado et al. (2014) argue, there are four different sectors representing the market and the non-market sector. Since it considers public administration data, the investigation is limited to the nonmarket public sector, hence the general government. In case of investments in public services, we checked that those were provided for free.

\footnotetext{
${ }^{9}$ As the document is no longer available online, the version accessed on the 21 April 2015 is available on request from the authors. Quantitative information collected in programme evaluation commissioned by the government did not become accessible for research purposes.
} 


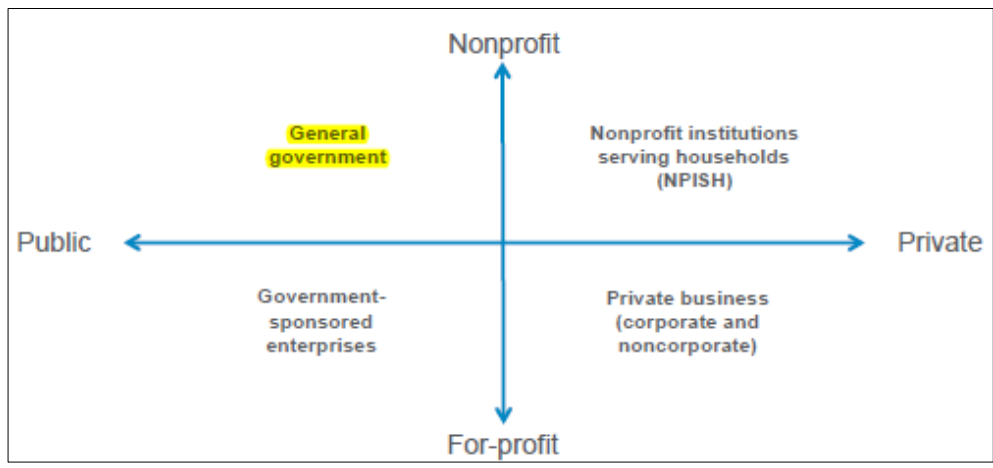

\subsection{Classification of Tangible Assets}

\subsubsection{Traditional Tangible Assets}

Traditional tangible assets include all assets that have a physical embodiment and can thus be touched, while not being information or communication technology. Examples for traditional tangible assets are for instance construction materials, as concrete, wood, or steel. Project A5 \#112 comes closest to this definition. One of the measures aims at the implementation of new doors.

\subsubsection{Hardware}

Not surprisingly, another category of tangible assets, which is the predominant one in this investment programme, is "hardware". Based on the definition of the Institute of Electrical and Electronics Engineers (IEEE), ${ }^{10}$ hardware is defined as physical equipment which is used to process, store, or transmit computer programs or data. It thus comprises all physical parts of a computer or another electronic device as well as the physical parts concerning network systems or broadband roll-out.

\section{Table 4: Key Words Hardware}

\begin{tabular}{|l|l|}
\hline $\begin{array}{l}\text { Backup and Hard Drive Storage } \\
\text { Systems ("Backup- und } \\
\text { Festplattenspeichersysteme") }\end{array}$ & $\begin{array}{l}\text { Grid-Connections } \\
\text { ("Netzanschlüsse") }\end{array}$ \\
\hline Blade Servers & $\begin{array}{l}\text { Efficiency ("Steigerung der } \\
\text { Leistungsfähigkeit") }\end{array}$ \\
\hline Broadband ("Breitband") & $\begin{array}{l}\text { Storage Capacity ("Erhöhung } \\
\text { der Speicherkapazität") }\end{array}$ \\
\hline Buildings ("Gebäude") & Monitors ("Monitore") \\
\hline Cabling/Wiring ("Verkabelung") & Networks ("Netze") \\
\hline $\begin{array}{l}\text { Emergency Power Supply } \\
\text { ("Notstromversorgung") }\end{array}$ & $\begin{array}{l}\text { Server } \\
\text { ("Datensicherungssysteme") }\end{array}$ \\
\hline Equipment/Device ("Geräte") & $\begin{array}{l}\text { Terminal Compartments } \\
\text { ("Anschlussräume") }\end{array}$ \\
\hline
\end{tabular}

\footnotetext{
${ }^{10}$ IEEE Standard Glossary of Software Engineering Terminology.

${ }^{11}$ Potentially included software/tools are regarded as operation system. For further explanation see category 4.2.1Software.

${ }_{12}$ Efficiency depends largely on processors which are defined as "Hardware".

${ }^{13}$ Projects aim at the consolidation or expansion of these.
} 


\subsection{Classification of Intangible Assets}

\subsubsection{Software}

The US Bureau of Economic Analysis (BEA) ${ }^{14}$ started in 1999 to include investment in software in its measure of business investment (Nakamura, 2001). Other countries followed.

The categorisation of a project as "software" is more difficult than as "hardware" since it is not always obvious that investment in software is included in a project. To make this more explicit, we start with the criteria we propose for categorising an asset as "software". We lean onto the definition of software given by the IEEE, ${ }^{15}$ which states that computer programmes and procedures as well as documentation or data relevant to the operation of a computer system are defined as software. Contrary to this definition, however, we restrict our category to solely including software that is irrelevant to the basic functioning of a computer. We exclude all software that hardware depends upon. This kind of software is not explicitly defined as software but is part of the hardware itself. Effectively, we abstract from any operation system as Windows or Linux ${ }^{16}$ but include "additional" software as for instance Adobe Acrobat, or the anti-virus software Kaspersky. ${ }^{17}$

The BEA distinguishes between prepackaged software, custom software and ownaccount software. ${ }^{18}$ As in most of the cases we were not able to determine the type of software, the category software comprises all three of them. Since the investment programme is targeted at purchases from external firms, we expect the share of ownaccount software to be low. Based on the project descriptions, we detect some frequently occurring elements of investment in software that are summarized in Table 5.

Table 5: Key Words Software

\begin{tabular}{|l|l|}
\hline $\begin{array}{l}\text { Application Server } \\
\text { ("Applikationsserver") }\end{array}$ & Protocol ("Protokoll") \\
\hline $\begin{array}{l}\text { Application Software } \\
\text { ("Applikationssoftware") }\end{array}$ & Solutions ("Lösungen") \\
\hline $\begin{array}{l}\text { Functions (“Erweiterung von } \\
\text { Funktionen") }\end{array}$ & $\begin{array}{l}\text { Server Virtualisation } \\
\text { ("Servervirtualisierung") }\end{array}$ \\
\hline $\begin{array}{l}\text { Penetration Tests } \\
\text { (“Penetrationstest") }\end{array}$ & $\begin{array}{l}\text { Standardisation } \\
\text { ("Standardisierung") }\end{array}$ \\
\hline $\begin{array}{l}\text { Portal/Web-Portal/Internet- } \\
\text { Portal }\end{array}$ & Tools ("Werkzeuge") \\
\hline
\end{tabular}

\footnotetext{
${ }^{14}$ For further information on the tasks of the Bureau of Economic Analysis see http://www.bea.gov/. [16.06.2015].

${ }^{15}$ IEEE Standard Glossary of Software Engineering Terminology.

${ }^{16}$ The current version is Windows $10:$ http://www.microsoft.com/de-de/windows/.

For more information on Linux see http://www.linux.com/.

${ }^{17}$ Adobe Acrobat can be downloaded on http://www.adobe.com/de/downloads.html.

For further information on Kaspersky see http://www.kaspersky.com/.

${ }_{18}^{18}$ Parker \& Grimm (2000).

${ }^{19}$ We refer to the standardisation with regards to Data, XML, DOL.
} 


\subsubsection{Concepts}

The analysis of the data led to the formulation of a category that is as such to our knowledge not explicitly formulated in previous research on intangibles (but is implicit to other categories used in that research). The category "concepts" comprises all projects dealing with the creation of concepts, studies, or analyses. Concepts or studies are usually created in order to plan for instance the design of a new product or the implementation of a new business process. Since concepts, studies and analyses offer a future benefit, the category qualifies for investment. We see this category as mainly belonging to the class "innovative property" in Corrado et al. (2015). But it may also occur in the class "economic competencies" (see Tables 11 and 12). The category "concepts" gives a description of some kinds of assets attributed to scientific and non-scientific research. Among others, it includes investment in the creation of manuals. The information given in a manual often supports employees in fulfilling their tasks. It leads to a more efficient process, especially concerning time and correctness and thus provides a future benefit. The criteria for projects to be categorised as "concepts" are straightforward. The title or the short description usually includes the information that work on a concept, study, or analysis has been done. We only categorise a project as "concepts" if it is specifically mentioned in the title or the short description that a concept, study, or analysis was the aim of the project.

Table 6: Key Words Concepts

\begin{tabular}{|l|l|}
\hline Analysis ("Analyse") & Manual ("Handbuch") \\
\hline Concept ("Konzept") & Planning ("Planung") \\
\hline Evaluation ("Evaluierung") & Strategies ("Strategien") \\
\hline $\begin{array}{l}\text { Feasibility Study } \\
\text { ("Machbarkeitsstudie") }\end{array}$ & $\begin{array}{l}\text { Survey and Description } \\
\text { ("Erhebung und } \\
\text { Beschreibung) }\end{array}$ \\
\hline
\end{tabular}

\subsubsection{Consulting}

We categorise a project as "consulting" if the measures include the purchase of external consulting services. According to Corrado et al. (2005) this category is included in "purchased organisational capital". Contrary to Corrado et al. (2005), we do not have to approximate the investment in consulting projects by the revenues of the management-consulting industry because we dispose of the specific spending amounts. To be classified as "consulting", it must be specifically mentioned in the title, the short description, or in other sources related to the project that expenses on external support existed. One drawback of this method is, however, that we cannot clearly distinguish between external and internal consulting services. Since the IT investment programme focused on the purchase of goods and services from external firms, this is a problem only to the extent that the external services were complemented by internal services. 


\begin{tabular}{|l|}
\hline Consultancy ("Beratung"20) \\
\hline Services (“Leistungen", "Dienstleistungen") \\
\hline Support (“Unterstützung") \\
\hline
\end{tabular}

\subsubsection{Organisational Capital}

The existing definitions of organisational capital are mostly related to business investment in intangibles. Corrado et al. (2005) for instance define two types of organisational capital and propose a method of their estimation. One of them is purchased organisational capital, which we already discussed in the previous category. Another type is the own-account organisational capital which they measure via the value of executive time. As already mentioned, the category "consulting" comprises all investment in purchased organisational capital. Corrado et al. (2014) argue that one of the major issues concerning the analysis of public sector intangibles is that the available data are different from those of the business sector. This also applies to the situation of our data. As we do not dispose of detailed data on the management services involved in the projects, we need to apply a different definition of own-account organisational capital.

Lev and Radhakrishnan (2005) refer to organisational capital as being "an agglomeration of technologies - business practices, processes and designs, and incentive and compensation systems - that together enable some firms to consistently and efficiently extract from a given level of physical and human resources a higher value of product than other firms find possible to attain".

In our context, a project is categorised as "organisational capital" if it modifies the internal, or organisational structure of a unit. This modification of the organisational structure of course can result from different types of projects. A project categorised as "organisational capital" aims at the implementation of new or at the modification of existing business processes with the goal to make them more (cost-) efficient and to simplify the workflow as well as to centralise different tasks in one unit. Projects targeting the harmonisation, unification and standardisation of methods are also categorised as "organisational capital". Projects aiming at a structural change of a process are as well included in this category. All of these objectives ideally lead to an organisational structure that allows a more efficient workflow. Especially in the case that processes relating several public authorities were previously cumbersome and slow-going, the criteria we propose imply an increase in the organisational capital by some of the measures implemented through the IT investment programme. Note that the definition only encompasses projects that meet the criteria without the help of external consultants. ${ }^{21}$

\footnotetext{
${ }^{20}$ The support must not be specified as being external.

${ }^{21}$ These belong to the individual category "consulting".
} 
Table 8: Key Words Organisational Capital

\begin{tabular}{|l|l|}
\hline Administration ("Verwaltung") & $\begin{array}{l}\text { Management Systems } \\
\text { ("Management Systeme") }\end{array}$ \\
\hline $\begin{array}{l}\text { Centralisation } \\
\text { ("Zentralisierung") }\end{array}$ & $\begin{array}{l}\text { Standardisation } \\
\text { ("Standardisierung") }\end{array}$ \\
\hline IT Security Management ("IT- & Unification \\
Sicherheitsmanagement") & ("Vereinheitlichung") \\
\hline
\end{tabular}

\subsubsection{Databases}

The category "databases" comprises all projects that specifically aim at the creation of a database. A project is categorised as "database" if it targets the construction or implementation of a database. We limit the definition to databases that focus on the provision of information. If data are freely available within the public sector, however, ambiguity may result from the fact that the actual provision of the data within the public sector or to outside actors may proceed by means of project investment in other categories, such as "concepts", "software" or "hardware".

Table 9: Key Words Database

\begin{tabular}{|l|}
\hline Database ("Datenbank") \\
\hline Archiving ("Archivierung") \\
\hline Knowledge platform ("Wissensplattform") \\
\hline Documentation ("Dokumentation") \\
\hline
\end{tabular}

\subsubsection{IT-Training}

The category "IT-Training" covers all investment in projects aiming at the training and coaching of employees regarding IT or IT-related tasks. It also concerns all projects dealing with outside contracts for providing IT-training to government employees. The projects are categorised as "IT-training" if it is clearly specified in the title, the short description, or in other project-related sources that expenses in connection with the training of employees incurred.

Table 10: Key Words IT-Training

\begin{tabular}{|l|}
\hline Training Course ("Schulung") \\
\hline Awareness Raising ("Sensibilisierung") \\
\hline
\end{tabular}

\subsubsection{Mixed Categories}

As argued in Alencar et al. (2013), IT projects are often split up into smaller subprojects. A project thus seldom belongs to only one category. It usually includes a number of measures with different aims. We therefore introduce the notion of mixed categories. If a project includes enough different measures to belong to each of the six categories, it is, for example, categorised as "software/concepts/consulting/ organisational capital/database/IT-Training".

One example of a mixed category project is A5 \#102. The project includes measures aiming at updating the IT baseline protection concept of the Waterways and Shipping

\footnotetext{
${ }^{22}$ We refer to the standardisation of processes or tasks.
} 
Directorate (WSD) Nordwest ${ }^{23}$ as well as at the creation of an initial IT baseline protection concept for the waterways and shipping offices of the division with the help of the GS-Tool. ${ }^{24}$ The project is hence categorised as "concepts". Moreover, the project targets at improving IT security in the respective departments as well as at introducing awareness-raising activities for employees regarding the security measures. The project therefore also belongs to the category "IT-Training". Eventually, the project is categorised as "concepts/IT-Training" indicating its dual nature.

Another example, which highlights the multiple facets of projects, is D4 \#6. The project aims at the development of the XÖV standard "XWaffe". ${ }^{25}$ Further, it includes the creation of a maintenance concept for the standard and for the conversion of functionalities regarding data correction of non-standardised values. The development of the standard is on one side a programming matter and can hence be categorised as "software". On the other side, the clear benefit of its development and implementation is related to costs and efficiency of business processes in this department. This perception of the measure leads to the category "organisational capital". As the second measure of creating a care concept obviously belongs to the category "concepts", the project's overall categorisation is "software/concepts/organisational capital".

\section{Grouping of Intangibles}

Corrado et al. (2005) define broad groups of intangibles (Table 11). We here group our individual categories according to their scheme (Table 12).

Table 11: Intangible Groups according to Corrado et al. (2005)

\begin{tabular}{|c|c|}
\hline $\begin{array}{c}\text { Name of } \\
\text { Group }\end{array}$ & $\begin{array}{c}\text { Type of Knowledge } \\
\text { Capital }\end{array}$ \\
\hline $\begin{array}{c}\text { Computerised } \\
\text { Information }\end{array}$ & $\begin{array}{c}\text { Knowledge embedded in } \\
\text { computer programs and } \\
\text { computerised databases }\end{array}$ \\
\hline $\begin{array}{c}\text { Innovative } \\
\text { Property }\end{array}$ & $\begin{array}{c}\text { Knowledge acquired } \\
\text { through scientific R\&D and } \\
\text { nonscientific inventive and } \\
\text { creative activities }\end{array}$ \\
\hline $\begin{array}{c}\text { Economic } \\
\text { Competencies }\end{array}$ & $\begin{array}{c}\text { Knowledge embedded in } \\
\text { firm-specific human and } \\
\text { structural resources, } \\
\text { including brand names }\end{array}$ \\
\hline
\end{tabular}

\footnotetext{
${ }^{23}$ For more information on the WSD Nordwest see http://www.wsv.de/wsd-nw/wir ueber uns/. [22.11.2016].

${ }^{24} \mathrm{GS}-\mathrm{Tool}$, available from:

https://www.bsi.bund.de/DE/Themen/ITGrundschutz/GSTOOL/Download/download_node.html. [22.11.2016].

${ }^{25} \mathrm{XW}$ affe is a standard supporting the efficient and profitable implementation of thorough and uninterrupted processes within the German weapon administration. The standard is defined as the binding standard for the surveillance of firearms. https://www.xrepository.de/Inhalt/urn:uuid:ae519e8882c1-4219-8c0a-99dd1a3af561.xhtml. [22.11.2016].

${ }^{\frac{82}{26}}$ As we consider the Federal Government, we abstract from brand names.
} 
Depending on the knowledge created, concepts may contain the results of research and development activities or they may describe specific organisational practices. Other potential output of R\&D, such as patents, was not observed in the Federal IT Investment Programme.

\section{Table 12: Intangible Groups - Categories}

\begin{tabular}{|c|c|c|}
\hline $\begin{array}{l}\text { Name of } \\
\text { Group }\end{array}$ & $\begin{array}{c}\text { Type of } \\
\text { Knowledge } \\
\text { Capital }\end{array}$ & $\begin{array}{l}\text { Categories } \\
\text { Intangibles }\end{array}$ \\
\hline \multirow{2}{*}{$\begin{array}{l}\text { Computerised } \\
\text { Information }\end{array}$} & \multirow{2}{*}{$\begin{array}{l}\text { Knowledge } \\
\text { embedded in } \\
\text { computer } \\
\text { programmes } \\
\text { and } \\
\text { computerised } \\
\text { databases } \\
\end{array}$} & a) Software \\
\hline & & b) Database \\
\hline $\begin{array}{l}\text { Innovative } \\
\text { Property }\end{array}$ & $\begin{array}{c}\text { Knowledge } \\
\text { acquired } \\
\text { through } \\
\text { scientific R\&D } \\
\text { and } \\
\text { nonscientific } \\
\text { inventive and } \\
\text { creative } \\
\text { activities }\end{array}$ & Concepts \\
\hline \multirow{4}{*}{$\begin{array}{c}\text { Economic } \\
\text { Competencies }\end{array}$} & \multirow{4}{*}{$\begin{array}{l}\text { Knowledge } \\
\text { embedded in } \\
\text { firm-specific } \\
\text { human and } \\
\text { structural } \\
\text { resources, } \\
\text { including brand } \\
\text { names }\end{array}$} & $\begin{array}{c}\text { a) } \\
\text { Organisational } \\
\text { Capital } \\
\end{array}$ \\
\hline & & b) IT Training \\
\hline & & c) Consulting \\
\hline & & d) Concepts \\
\hline
\end{tabular}

\subsection{Classification of Mixed Projects}

Apart from the possibility of multiple categorisations within the class of intangibles, it is likely that a project includes investment in tangible and intangible assets at the same time. It is then classified as "tangible/intangible". As we base the assessment on mostly qualitative information, we include project-specific comments and assumptions in the project database to explain the reasoning for the classification and categorisation. We face in total three different situations, in which a project is classified as "tangible/intangible". 


\subsubsection{Classification}

\section{No Information available}

For some projects, the information available is insufficient and opaque.

Project A5 \#24 is a good example for this situation. The only information available is that it aims at guaranteeing confidentiality for the use of mobile IT and data exchange. With these few facts, we are not able to adequately classify the data. We here assume that guaranteeing the confidentiality for the use of mobile IT includes intangible as well as tangible assets. A protocol or a programme written for this matter would count as an intangible asset. Similarly, the creation of a concept could also be a part of this project. On the other hand, it could include the use of security hardware tokens needed for the authentication when using mobile working solutions. As a result, we classify the project as "tangible/intangible".

Another related project is project B3 \#39. Neither the title nor the short description nor any other project-related sources provide clear information on the intangible share of the investment. The only insight we obtain is that the measures are targeted at the increase in the availability of IT services and IT equipment to ministry standards. We assume that the project could comprise investment in software, programming or concepts as well as investment in new hardware or cabling. By classifying the project as "tangible/intangible" we thus account for investment in both types of assets.

\section{Little Information}

Another possible situation to face is that the project's sources give enough information to conclude that intangible and tangible investment should be included. Still, there is no specific mentioning of investment in software or hardware. Project A5 \#43 serves as an example for this case. The project aims at the procurement and implementation of a certified firewall. ${ }^{27}$ The term "firewall" is very general and does not specify whether it refers to a hardware-based, a software-based or a mixed firewall set-up. In order to account for the possible inclusion of hardware and software, we classify the project as "tangible/intangible".

Another typical project is D3 \#11. The project aims at the implementation of a new internet portal. This cannot work without a server, but also requires programming. This is however not specifically mentioned in any of our information sources. We classify the project as "tangible/intangible".

\section{Good Information}

For some projects it is possible to conclude from the sources that investment in tangible as well as into intangible assets was made.

\footnotetext{
${ }^{27}$ Certification carried out by the Federal Office for Information Security. An example can be found for the GeNUScreen 2.0 Firewall. Press release available from:

https://www.bsi.bund.de/DE/Presse/Pressemitteilungen/Presse2009/Zertifikatsuebergabe_Genua_Ma sktech_15012009.html. [22.11.2016].
} 
Project C2 \#73 is concerned with the implementation of efficient desktop systems through the migration from Windows Office 2007 to Windows $7^{28}$ The short description gives us additional information on the individual measures. Investment was made on hard drive storage systems, band storage systems and storage area network (SAN) switches. These all belong to "hardware" and should hence be classified as "tangible". According to the description, the purchase of software was also part of the project. We thus find clear evidence on mixed investment and are able to classify the project as "tangible/intangible".

Another typical project is D5 \#17. It aims at the development of a new research portal and the further development of the open source software (OSS) search engine YaCy. ${ }^{29}$ The short description mentions that the measures include the replacement of old hardware, which can be clearly classified as "tangible". Moreover the project comprises the implementation of Green IT products to save energy and space as well as the introduction of a new design and additional functionalities for the OSS search engine. The part concerning the OSS search engine clearly includes solely investment in intangible assets. In conclusion, the project is classified as "tangible/intangible".

\subsubsection{Shares}

Since certain projects are classified as "tangible/intangible" it becomes necessary to determine the amount of investment spent on the intangible assets and tangible assets. As we base our assessment on qualitative information, we are forced to make certain assumptions regarding the categorisation of projects as well as regarding the approximation of the investment in intangible assets. We use specific examples to explain our approach. First, we discuss the assumptions for the categorisation. In a second step we explain the reasoning for the approximation of the intangible share of the project.

\section{Calculation}

For a few projects within the database, we are able to calculate the exact intangible share of the investment. We refer to project $A 1 \# 1$ which has a quite large budget of $€ 12,709,706$. The information coming from the title and the short description are not sufficient for the calculation of shares of investment in individual categories. We moreover found the project's enactment, ${ }^{30}$ which includes more detailed information. For instance, it contains information on the number of mobile phones purchased as well as the information that the creation of a new standard regarding the compatibility of the products was part of the project. Another important source of information for this project is a document from the German Bundestag regarding safety in mobile

\footnotetext{
${ }^{28}$ See Microsoft homepage for further information. Available from: http://www.microsoft.com/. [22.11.2016].

${ }^{29} \mathrm{YaCy}$ is a free-of-charge search engine.

${ }^{30}$ The respective enactment 16/2009-Attachement 03 -Measure A.-1.1 can be found on http://www.cio.bund.de/Web/DE/Politische-Aufgaben/IT-

Rat/Beschluesse/Tabelleninhalte/beschluss 16 2009.html?nn=4623828. [22.11.2016].
} 
telephony. ${ }^{31}$ It offers specific information on the type of the crypto phone purchased as well as the number and the price. A total of 499 TopSec mobile phones were purchased at a price of $€ 1,260$. Around 1,500 Secuvoice ${ }^{32}$ mobile phones were purchased at a price of $€ 1,200$. It is further mentioned that 3,250 additional mobile phones should be purchased however without specific information on the type or the price. To be able to take these additional mobile phones into account, we use the average price calculated from the given prices as an approximate price for the additional mobile phones. Being the only source of tangible investment in this project, we simply need to multiply the number of phones with their prices and add up the resulting values. The total value of money spent on the crypto phones is then used to calculate the share of investment in tangible assets. Information is unfortunately not as detailed for other projects.

\section{Assessment of the Intangible Share}

A project holds a zero share of investment in intangible assets if we only find information on investment in tangible assets and can exclude the possibility of investment in intangible assets. ${ }^{33}$ We choose project C2 \#14 for illustration. The project's goal is to replace old monitors with new, energy saving monitors.

The principle is analogous for an intangible share of one. If the project-related sources indicate that solely investment in intangible assets was undertaken and we can exclude the possibility of investment in tangible assets, the intangible share of these projects is set to one. Project D3 \#8 serves as an example. It aims at the preparation of a feasibility study regarding the electronic tariff register. Specifically, the study includes an analysis of whether the digitalisation of the tariff register is in line with the copyright law and whether the electronic mailing of tariff contracts is allowed. Further, the project aims at evaluating the technical implementation of the concept and at proposing concrete solutions where possible. We thus do not find any reference of investment in tangible assets but solely investment in the feasibility study and a concept which are both categorised as intangible investment. The entire amount of money invested is thus spent on intangible assets.

The approach for mixed projects is more complex. Due to the lack of detailed information, we necessarily approximate the intangible share of certain projects. In a first step, we try to assess, based on the information we obtain from the basic sources as the title or the short description, whether investment in tangible assets is larger than investment in intangible assets. The individual measures of the projects are often further described without, however, details on the costs. As a consequence, we need to approximate the share of intangible investment for each project. We do

\footnotetext{
${ }^{31}$ The price details are given on page 3 of the document. Available from: http://dip21.bundestag.de/dip21/btd/17/010/1701072.pdf. [22.11.2016].

${ }^{32}$ TopSec Mobile is a mobile encryption device. For further information see https://www.rohdeschwarz.com/en/product/topsec-mobile-productstartpage 63493-10284.html. [22.11.2016].

Secuvoice allows for secure communication. For more information see https://www.secusmart.com/en/. [22.11.2016].

${ }^{33}$ As a comparison, we refer to the cases "Little Information" or "No Information" for which we have not been able to exclude the possibility of investment in intangible assets.
} 
this by using the number of individual measures we can identify in a project concerning investment in intangible assets and divide it by the project's total number of individual measures.

Project A5 \#8 serves as an example for an intangible share of one third. The short description provides us with the following information on the project: The individual measures of the project are intended to improve the IT security. The investment is directed at the replacement of data-backup systems, the purchase of the software AdminStudio and the acquisition of SINA-VW. ${ }^{34}$ The data-backup systems as well as the SINA-VW are categorised as "hardware" and are hence classified as "tangible". The software AdminStudio belongs to the category "software" and is hence classified as "intangible". Hence there are a total of three measures of which two are classified as "tangible" and one as "intangible". We conclude that approximatively one third of the investment amount is spent on intangible assets.

To demonstrate the procedure for a project with an intangible share of two thirds, we consider project D4 \#18. The project aims at the implementation of an information and communication platform for the comparison of national and international control standards for organic food products. Compared to the previous project, the information provided on the individual measures is not as detailed. From the title we are able to deduct that a tangible and an intangible part exist. Moreover, it is reasonable to assume that the tangible part consists of the servers needed to run the platform. We suggest that the intangible part is divided into the categories "software" and "databases". The platform serves as an information provider and programmes as well as protocols are needed to implement and to run it. We therefore have two out of three measures aimed at investment in intangible assets which entails an assumed intangible share of two thirds.

The special case of assumed equal shares of investment in intangible and tangible assets can result from two different approaches. First, it can be the result of the division of the number of measures concerned with intangible investment by the project's total number of measures. Another possible situation however is that we do not dispose of any information on specific measures.

One example is the project A5 \#24 described already in the previous section. The only information we hold is that the project's aim is to guarantee confidentiality for the use of mobile IT and data exchange. This information is quite unspecific and individual measures within the project cannot be identified. Since the project was classified as a mixed project and we do not have any further information, we assume equal shares for intangible and tangible investment.

After setting out the approximation approach, we now give further examples of assets included in several projects' measures, for which we needed to make assumptions.

\footnotetext{
${ }^{34}$ The software AdminStudio provides application packaging tools. The SINA Virtual Workstation is used for cryptographic means. Further information is available from: https://www.fox-it.com/nl/files/2012/05/SINA Brochure.pdf. [22.11.2016].
} 


\section{Firewall or Firewall Architecture}

There exist several types of firewalls, software- or hardware-based or a mix of both. As the only information provided for the respective projects is that the investment was made for a new firewall, we need to make an assumption about the type of firewall. To account for all of the three possible types, we simply assume that the firewall consists of an equal mix of hardware and software. Thus, for our purposes we classify investment in a firewall as "tangible/intangible", the intangible part being categorised as "software", and with equal share of tangible and intangible investment.

\section{IT Infrastructure}

Except for the case that a specific description of the parts of the infrastructure is given, as for project $A 1 \# 1$, we need to make an assumption about its nature. Project B3 \#39 illustrates the approach taken in this case. The project-related sources do not provide any specific information on the individual parts of the IT infrastructure except for the fact that they are supposed to increase the availability of IT services and IT equipment. We hence assume that investment in intangible assets as well as in tangible assets are undertaken. According to Agarwal, Santos and Starikova (2014) IT infrastructure consists of hardware, software and operational support. It could include data centres, networks and databases as well as software and software tools, thus tangible and intangible assets. To account for this fact and to avoid possible over- or underestimation, we assume equal shares of investment in tangible and intangible assets.

\section{Communication systems}

We here focus on all projects aiming at the purchase or implementation of communication systems such as video conferencing equipment and tools as well as telecommunication systems. If it is not explicitly stated what kind of equipment has been purchased we cannot decide whether intangible or tangible assets were purchased. To avoid possible over- or underestimation, we assume equal shares for investment in tangible and intangible assets.

\section{Website/Online Portal}

An assumption we make for measures with the goal to implement a new website or online portal is that we include a tangible part although it is not explicitly stated. We assume that the purchase or installation of new servers is included in the measures of the project. The goal of project D3 \#11 is to set-up an interactive internet portal for people searching for information and help regarding dementia. ${ }^{35}$ We assume that new servers are needed to run this new platform. As no additional information is provided, we can only assume that half of the investment was spent on the purchase of new servers. Considering that we ignore the number of servers needed and that

\footnotetext{
${ }^{35}$ For more information see http://www.wegweiser-demenz.de/startseite.html. [22.11.2016].
} 
the prices for servers vary substantially depending on the type and the brand, ${ }^{36}$ this might lead to either an under- or overestimation of the tangible part.

\subsection{Classification of E-Government Processes}

E-government processes are business processes related to governance and administration that are carried out with the support of ICT. The importance of egovernment has been steadily rising in the past years. With the increasing use of the internet in every area of life, the interaction of the government with other departments or institutions, with businesses and with citizens needs to adapt to this environment. Szkuta et al. (2014) and other authors criticise that most e-government services are still not user-centred enough. Moreover they argue that in times of crisis, governments are more reluctant to investing in e-government projects. It is thus of interest to us to what extent the Federal IT Investment Programme contributed to the improvement of e-government during the recession. To observe this, we need an approach to classify projects as related to e-government.

The definition of e-government we use is based upon the Speyer definition (Lucke and Reinerman, 2000). According to this definition, a project is related to egovernment if it aims at the execution of business processes related to governance and administration. Further, the task needs to be carried out with the support of information and communication technologies via electronic media. The definition of egovernment we apply also includes projects that support the future execution of such processes. We consider project B3 \#28 for illustration. The project aims at setting up an infrastructure for electronic forms. It is not specified that this would influence or create a business process. Still as the infrastructure represents a prerequisite for future business processes, we include the project into our class of e-government projects.

Based on the data, we choose two types of categorisation defined in the Speyer definition of e-government. We distinguish between different interaction levels of egovernment, namely "information", "communication" and "transaction". Additionally, we determine whether the processes take place within the public sector (G2G), between the government and citizens (G2C), or between the government and businesses (G2B). To be able to do so we must first define specific criteria for the different categories.

\subsubsection{Information}

Projects categorised as related to "information" comprise all e-government projects that aim at the introduction of new options to access and gather information as well as those aiming at an increase or modification of the information content.

\section{Examples}

We choose project D3 \#9, which is associated with the introduction of a new information source, as an example. The project's aim is to digitalise the tariff register

\footnotetext{
${ }^{36}$ As a reference, we use the Oracle Technology Global Price List from June 2015.
} 
in order to adapt the information possibilities to the information technology at that time. The first step is to scan all tariff contracts. The measure targets the general public, the parliament, the Federal Government and the respective ministry. With the possibility to access information on tariff contracts at any time from different locations, a significant amount of time and money is saved. Business processes relying on this information are thus more efficient.

Project D3 \#15 constitutes another interesting example to show new information possibilities. The project's goal was to implement a databased online tool which can be used by women and their families to calculate their individual economic benefit of returning to the labour market after a family leave. Additionally, it is possible to access the tariff databases in order to view indications on wages. It gives the possibility of easily finding out whether the return to the labour market pays off. It consists of a new information possibility with electronic media giving people the chance to access information straightaway without the need to turn up at a government agency. This increases the efficiency of government employees.

\subsubsection{Communication}

Projects categorised as related to "communication" need to aim at the creation of new communication opportunities. Specifically, they should have the goal to introduce new possibilities for participation and dialogue by the use of electronic media. This can include, among others, the purchase of communication equipment.

\section{Examples}

One project belonging to this category is $A 5 \# 50$. Its goal is to upgrade the existing network infrastructure in order to enhance the future use of internet protocol (IP) real time communication. It supports the safe transmission of voice and pictures in real time. The measure therefore creates a new possibility for communication between different departments and institutions, which leads to lower costs than telephone calls, especially international calls. Moreover, the efficiency increases, as parts of business processes are shifted towards a technology that only requires access to the internet independent of the location or time. The major focus however is on the communication aspect.

\subsubsection{Transaction}

Projects categorised as related to "transaction" aim at the introduction of new options to perform business tasks with electronic support. They involve the implementation of new business tasks and processes such that they support and simplify the electronic processing of requests.

\section{Examples}

Project A5 \#33 serves as a first example. It involves the purchase of finger print scanners. They are needed for the verification of the new German identity card in the context of border controls. Moreover, they are used for the purpose of personal 
identification within the European visa information system regarding air and sea borders. Obviously, they influence a business process, namely the control.

Another example is given by project B3 \#13. Its goal is the development of a service platform. The measure involves the development of a unified service platform for all cross-sectional processes. Moreover, it electronically supports business processes on a cross-application basis as well as work time management. The project clearly supports the electronic execution of business processes and introduces a new possibility to simplify the work process. It is thus categorised as related to "transaction".

\section{Mixed Categories}

The previous projects served as examples for "pure" categories. However, a project can include several measures with different focal points and hence belong to different categories.

\section{Examples}

An example which fits into this category is project D4 \#8. The project's goal is to develop an internet portal to pool the access to electronic statistic procedures concerning the transfer of data and the communication with the responsible agent. Moreover, it is specified to include functionalities concerning a personalised surface, the interaction of customers with the data reception management, and evaluation tools. As the functionalities enable the users to inform themselves, to communicate with the respective government employees, and to use the data for purposes concerning business processes, the project is categorised as related to "information/communication/transaction".

Another project categorised as a mixed is D3 \#11 (already presented in section 4.3.2). The major aim of the project is to create a website where people searching for information and help on dementia are able to find support. As the website provides not only information but also possibilities to communicate with employees of the ministry and to interact with other people via an online forum, the project is categorised as "information/communication".

Another project involving more than one category is project B3 \#34. Its goal is to better integrate deaf employees into the work process. This is done by the implementation of a central solution for video communication with deaf employees and employees suffering from a severe hearing loss. Additionally, it intends to introduce specific sign language and interpretation services for the communication with other colleagues. The measures therefore aim at a new communication possibilities for deaf colleagues which has a direct impact on relevant business processes. The project is thus categorised as "communication/transaction".

An e-government project can also be categorised with respect to the interaction partners of the process concerned. These can be businesses, citizens, or other government institutions. 


\subsubsection{G2B}

A project is categorised as "G2B" if it influences the interaction between the public sector and the business sector. Throughout our analysis we discovered that the main objective of all "G2B" projects was to reduce the workload on businesses and facilitate their interaction with the government regarding for instance requests.

\section{Examples}

A project having this kind of goal is project D3 \#6. It aims at the development of an online reporting procedure concerning the Renewable Energies Act Solar Register. ${ }^{37}$ The target of the measure is to reduce the burden for businesses in reporting procedures for photovoltaic installations. Before its implementation, businesses needed to fill out a special paper-based form and send it in via post, fax or e-mail. It was then further processed manually.

Another project we consider for illustration is D4 \#36. The aim is to guarantee a uniform processing without any media disruptions in processes of the online portal of the Federal Institute for Materials Research and Testing. ${ }^{38}$ In order to ensure a completely electronic process chain, the processes of integrated systems and document management systems as well as the communication with national and international partners were taken into account first. This should guarantee a consistent treatment of the documents in order to eliminate possible media disruptions. The project furthermore targets the introduction of the electronic signature in this context. The target group of this project is the business sector. We therefore categorise the project as "G2B".

\subsubsection{G2C}

Projects concerning the interaction of the public sector with its citizens are categorised as "G2C". We found that the major focus of "G2C" projects is on giving citizens access to information and services. Unlike "G2B" processes, where the aim is to simplify the existing interaction between government and businesses, the target of "G2C" projects is to introduce new possibilities for citizens to interact with the government.

\section{Examples}

A good example for this category is project D1 \#5. The project is linked to the introduction of the new identity card. Information on all activities concerning the new identity card can be requested at a central help desk. The aim of the project is to introduce new services and new forms of support for those citizens contacting the

\footnotetext{
${ }^{37}$ The online register can be accessed through https://app.bundesnetzagentur.de/pv-meldeportal/. [22.11.2016].

Information on the Renewable Energies Act ("Erneuerbare Energien Gesetz") are available from: http://www.erneuerbare-energien.de/EE/Navigation/DE/Recht-Politik/Das EEG/das eeg.html. [22.11.2016].

${ }^{38}$ Information concerning the Federal Institute for Materials Research and Testing are available from: https://www.bam.de/Navigation/DE/Home/home.html. [22.11.2016].
} 
central help desk regarding the blocking of online functions in case of loss of the identity card. This project solely targets citizens and is thus categorised as "G2C".

Another example of a "G2C" project is D3 \#5. Its goal is to develop a special website directed at children concerning the activities of the Federal Office of Civil Protection and Disaster Assistance. ${ }^{39}$ Additionally, it aims at expanding and modifying the information content on the website in an understandable and interesting manner in order to familiarise children with the matter of civil protection. The project is thus solely targeted at citizens and we categorise it as "G2C".

\subsection{6. $\mathrm{G} 2 \mathrm{G}$}

A project is categorised as "G2G" if it concerns the interaction of different public authorities. We found that the main focus of such projects is on supporting and facilitating the exchange of information and business tasks between public agencies. Specifically, the major goal was to introduce solutions targeting the electronic exchange of information such that it can be easily incorporated in further business processes. Moreover, specific attention was given to the development of media and data interfaces that allow a business process touching different public authorities to be carried out in a smooth way.

\section{Examples}

One example supporting this observation is project D4 \#41. It aims at the creation of a data interface for the construction cost control system Kameralis ${ }^{40}$ and software by $\mathrm{SAP}^{41}$ used as a budget control system. The project includes several measures as for instance the synchronisation of supplier data in KAMERALIS, in the construction registry, and in SAP as well as the connection of the systems via a supplier data interface. The project benefits solely interaction within the public sector and is hence categorised as "G2G".

Another project in this category is D5 \#8. It includes measures aiming at the development of an $\mathrm{XML}^{42}$-based data format and data exchange which needs to be in accordance with the XÖV standard ${ }^{43}$ and is used for legislative texts. The intention is to avoid the dependence on document formats solely operable on proprietary computers and to enable the connection of additional applications in the process chain of legislative procedures. This leads to a more efficient execution of tasks within the public authorities and is hence categorised as "G2G".

\footnotetext{
${ }^{39}$ Information concerning the Federal Office of Civil Protection and Disaster Assistance (BBK) is available from: http://www.bbk.bund.de/EN/Home/home node.html. [22.11.2016].

The respective website for children can be accessed under http://www.bbk.bund.de/SubSites/KI/DE/Home/home node.html;jsessionid=F10E37D9E3E01EE8055 87ED8944B4BB4.1 cid345. [22.11.2016].

${ }^{40}$ For more information on Kameralis, see http://www.kameralis.de/produkt.html.[22.11.2016].

${ }^{41}$ SAP stands for Systems, Applications, and Products in Data Processing. For more information see the company's website under http://www.sap.com/. [22.11.2016].

${ }^{42} \mathrm{XML}$ stands for Extensible Markup Language. For more information see http://www.xml.com/. [22.11.2016].

${ }^{43}$ The different XÖV standards are available from:

http://www.xoev.de/sixcms/detail.php?gsid=bremen02.c.738.de. [22.11.2016].
} 


\section{Mixed categories}

Apart from individual categories, a substantial part of the programme's projects are categorised as a mixed. This happens if a project includes measures which target more than one group.

\section{Examples}

A project that reflects this kind of mixture is B3 \#28. It aims at developing an infrastructure for electronic forms based on the form management system of the Federal Government. ${ }^{44}$ Further, it targets the integration of the electronic signature and various applications of the Federal Ministry of Transport and Digital Infrastructure. As forms and the electronic signature simplify certain procedures for business and citizens, we conclude that the development of the infrastructure influences not only intra governmental business processes but also processes touching businesses or citizens. We thus categorise it as "G2B/G2C/G2G".

Another project fitting a mixed category is B3 \#10. This project concerns the development of an interface package regarding electronic tendering. It aims at increasing the interoperability of the tendering platform and making it more open to access from third party systems. Businesses and other public authorities thus do not need to use a specific system in order to be able to use the platform. This results in an easier handling of the procedures for businesses and for other government institutions. The project is thus categorised as "G2B/G2G".

A further project categorised as a mixed is A4 \#1. It involves measures aiming at providing the citizens with an IT security kit in order to foster the usage of applications based on the new identity card. It includes a card reader and specific software. The benefit for businesses lies in the increased usage of those applications that need an identity card as a support. ${ }^{45}$ It simplifies and accelerates business processes. The project's major target group are the citizens as they are encouraged to make wider usage of the new identify card. The project is thus categorised as "G2B/G2C". Expenditure shares are allocated to the different e-government categories in a way analogous to the method applied to different categories of intangibles.

\footnotetext{
${ }^{44}$ Information on the form management system of the Federal Government can be accessed under https://www.formulare-bmf.del. [22.11.2016].

${ }^{45}$ One example is the registration for the customer portal of the Allianz insurance company. A list of examples can be found under http://www.personalausweisportal.de/DE/Buergerinnen-und-

Buerger/Anwendungen/Anwendungen node.html. [22.11.2016].
} 


\section{Results on Intangible Investment and E-Government}

\subsection{Spending on Intangibles}

Table 13 shows the share of investment within each of the four pillars in the investment programme that was made in different project categories: projects creating only tangible assets, projects creating only intangible assets and mixed projects. For the mixed projects, the estimated shares of tangible and intangible spending are reported. The final row also shows the relative investments in the four different pillars. About half of the spending within the programme went into IT security. The other three pillars, IT organisation, Green IT and Innovation, are of similar size.

In IT security, we find the highest share of spending in projects with tangibles only (more than 42 percent). The pillar Innovation has the highest share of spending on purely intangible projects with 62.5 percent. Over all pillars, our estimated shares for the four categories (tangibles/intangibles only, tangible/intangible share within mixed projects) are all between 20 and 30 percent. The pillar Green IT has the highest share of spending in mixed projects.

Table 13: Share of Different Project Categories in Percent

\begin{tabular}{|c|c|c|c|c|c|}
\hline Intangible Shares & IT security & $\begin{array}{c}\text { IT } \\
\text { organisation }\end{array}$ & Green IT & Innovation & $\begin{array}{c}\text { Investment Share } \\
\text { Total Amount }\end{array}$ \\
\hline Projects with Intangibles Only & 7.1 & 44.2 & 5.4 & 62.5 & 23.8 \\
\hline Projects with Tangibles Only & 42.6 & 0.0 & 23.0 & 0.5 & 24.5 \\
\hline $\begin{array}{c}\text { Mixed Projects - Intangible } \\
\text { Share }\end{array}$ & 28.7 & 25.5 & 33.7 & 28.4 & 29.0 \\
\hline $\begin{array}{c}\text { Mixed Projects - Tangible Share } \\
\text { Total }\end{array}$ & 100.0 & 100.0 & 100.0 & 100.0 & 22.7 \\
\hline $\begin{array}{c}\text { Share of Pillar in Total } \\
\text { Investment }\end{array}$ & 49.0 & 15.3 & 15.4 & 20.4 & 100.0 \\
\hline
\end{tabular}

In Table 14, we consider spending on intangible assets only. It has to be emphasized again that we were unfortunately unable to obtain direct information on spending per category for most projects. So the results rely on our estimation procedure combining qualitative information with assumptions on spending shares. According to the estimations, nearly half of the intangible investment in the programme went into software. The share was slightly above 3 percent in the pillars IT security and IT organisation and nearly 75 percent in the pillar Green IT. The next largest category is spending on consulting, followed by organisational capital and concepts. Spending on databases and training is very low according to our approximations. Expenses on consulting make up half of the intangible spending in IT security projects. 
Table 14: Intangible Investment by Category in Percent

\begin{tabular}{|c|c|c|c|c|c|}
\cline { 2 - 6 } \multicolumn{1}{c|}{} & IT security & $\begin{array}{c}\text { IT } \\
\text { organisation }\end{array}$ & Green IT & Innovation & $\begin{array}{c}\text { Share in Total } \\
\text { Intangible } \\
\text { Investment }\end{array}$ \\
\hline Software & 37.6 & 36.0 & 74.7 & 51.5 & 46.4 \\
\hline Concepts & 7.3 & 9.6 & 10.8 & 13.4 & 10.3 \\
\hline Consulting & 48.3 & 15.3 & 5.1 & 15.2 & 25.1 \\
\hline Organisational Capital & 1.9 & 37.1 & 9.4 & 15.0 & 14.5 \\
\hline Databases & 0.4 & 1.9 & 0.0 & 4.6 & 2.1 \\
\hline IT-Training & 4.5 & 0.1 & 0.0 & 0.3 & 1.6 \\
\hline Total & 100.0 & 100.0 & 100.0 & 100.0 & 100.0 \\
\hline
\end{tabular}

\subsection{Spending on E-Government}

We now aim at investigating the nature of the IT investment programme in the context of e-government. We look at the different dimensions of e-government individually. First, we examine the distribution of funds across the e-government categories "information", "communication", and "transaction". The goal of this analysis is to find out whether the focus was on improving and introducing new possibilities to access information provided by the public organisations, on introducing new communication opportunities or on creating and facilitating business processes.

Second, we approach the relationship dimension of e-government. We direct the analysis at the allocation of funds across the three categories "G2B", "G2C", and "G2G".

Table 15 shows that e-government spending is estimated at around 90 percent in the pillars IT organisation and Innovation and at around 30 percent in the two other pillars. Where e-government spending is low, its intangible share exceeds the intangible share in the non-e-government spending within the pillar. 
Table 15: Intangible Spending Differentiated by E-Government and Other Projects in Percent

\begin{tabular}{|c|c|c|c|}
\cline { 2 - 4 } \multicolumn{1}{c|}{} & Share e-government & $\begin{array}{c}\text { Share intangibles } \\
\text { in e-government }\end{array}$ & $\begin{array}{c}\text { Share intangibles in } \\
\text { other spending }\end{array}$ \\
\hline IT security & 29.2 & 57.8 & 26.8 \\
\hline IT organisation & 87.3 & 67.1 & 87.6 \\
\hline Green IT & 30.0 & 50.0 & 34.4 \\
\hline Innovation & 91.3 & 90.5 & 96.1 \\
\hline
\end{tabular}

In Table 16, we see that most of the e-government spending is targeted at processes within government, nearly the totality in the pillars IT organisation and Green IT and around half in the pillars IT Security and Innovation. The weight of spending on G2Band $\mathrm{G} 2 \mathrm{C}$-e-government is about equal within the pillars.

Table 16: E-Government Spending by the Categories G2B, G2C and G2G in Percent

\begin{tabular}{|c|c|c|c|c|}
\cline { 2 - 5 } \multicolumn{1}{c|}{} & IT Security & $\begin{array}{c}\text { IT } \\
\text { Organisation }\end{array}$ & Green IT & Innovation \\
\hline G2B & 20.8 & 1.7 & 5.4 & 24.3 \\
\hline G2C & 22.7 & 1.1 & 3.2 & 29.0 \\
\hline G2G & 56.5 & 97.2 & 91.4 & 46.7 \\
\hline
\end{tabular}

With regard to the nature of the processes enhanced by e-government investment, transaction processes are the most important processes in three out of the four programme pillars. Spending on information processes make up nearly 30 percent in the pillar Innovation, the share spent on communication processes is highest in Green IT with about 50 percent.

Table 17: E-Government Spending by the Categories Information, Communication and Transaction in Percent

\begin{tabular}{|c|c|c|c|c|}
\cline { 2 - 5 } \multicolumn{1}{c|}{} & IT Security & $\begin{array}{c}\text { IT } \\
\text { Organisation }\end{array}$ & Green IT & Innovation \\
\hline Information & 17.8 & 21.7 & 10.4 & 29.2 \\
\hline Communication & 33.3 & 25.4 & 51.5 & 9.7 \\
\hline Transaction & 48.9 & 52.9 & 38.1 & 61.1 \\
\hline
\end{tabular}


Since the budget of the Federal IT Investment Programme is spent on purchased assets, we do not have data of own-account assets created in conjunction. For example, data on IT training probably only cover the cost of purchasing the training services but not the wage cost of government staff attending the training.

\subsection{Investment in Databases}

When we think of different kinds of value that an anti-crisis IT spending programme could provide to the economy as a whole, the aspects directly targeted by the programme where efficiency and quality of government services and turnover and employment in the German IT sector. More general, indirect targets were described by the four blocks that projects were grouped in. Beyond that, one can ask in how far the programme contributed to provide not only government services but freely available intangible assets to business and citizens.

If we look at the list of intangible assets considered in this paper and keep in mind that the programme was not a classical R\&D programme, the assets that could be most likely provided not only within government but also to outside parties are software and databases. New software provides value outside government in cases where it could be used for e-government purposes or for accessing information provided by the government. Databases can be provided within the government or to the general public. In recent years, increasing attention has been paid to the potential that the publication of government data (e.g. geographical data) has for the creation of new data-based services by the private sector. A European country where initiatives for "open data" have been quite active is the UK. ${ }^{46}$ Corrado et al. (2015) discuss that database creation within the public sector has a purpose that is often fundamentally different from the purpose in the private sector.

The Federal IT Investment Programme had a focus on innovation, which could include this aspect, but it had no specific emphasis on open data. The percentage of the budget spent on databases was quite low with 2.1 percent, and not all these databases were "open".

We noticed that some projects in other categories, such as "software", "concept" or "tangible", were also targeted at the creation of databases. The idea of "open data" is to publish data that are not collected for that purpose but that are available as a byproduct of other government activity. So it could in fact be expected that the cost for the data themselves is low, but that investment in other assets is necessary to make the database running online. In addition to the 2 percent directly invested in databases, we found that a bit more than 5 percent of the programme budget is invested in other assets supporting the creation of databases. This includes databases within government that are not "open", but that could also be the basis for further innovation within that sector. For example, $€ 8$ million were invested into software and organisational capital related to the "German Digital Library". Around $€$ 2 million were invested into the "Geodata Infrastructure Germany", of which only a

\footnotetext{
${ }^{46}$ For more information see https://data.gov.uk/. [22.11.2016]
} 
minor part was direct spending on data. Since increasing digitalisation in all areas of life creates an increasing amount of data as by-product, the valuation of investment in databases will often face this issue that monetary investment to make the database run covers a number of other intangible assets. With regard to the Federal IT Investment Programme, we still come to the conclusion that database creation was only a minor outcome when compared to the amount invested, e.g., into improving IT security.

\section{Comparison of Results to Regular IT Spending at the Federal Level}

In a next step, we investigate the feasibility of comparing the intangible IT spending in the anti-crisis programme and the insights gained on asset creation to regular IT spending at the German federal level. Considering budget information, the overall magnitude can be compared but there is little comparability at the category level. Further comparison might be possible collecting more detailed information from individual ministries and other institutions belonging to Federal Government.

\subsection{Classification of IT Spending in the German Federal Budget}

The German Federal Budget is partitioned in detailed plans which are assigned to administrative departments (department principle) and certain subject groups (functional principle). Subject groups in the German Federal Budget are Federal Debt and General Financial Administration. The sum of the IT spending in each detailed plan yields the total federal IT spending.

For convenience, we shall only mention the departments in the following when in fact we mean both the administrative departments as well as the subject groups. Prior to 2013 each department had to account its spending on IT in a separate title group ("Titelgruppe 55 - Ausgaben für die Informationstechnik (Spending on IT)") as long as there was more than one title to consider (Leibinger et al., 2014). The exact structure of title group 55 is given in the table below.

Table 18: Title group 55

\begin{tabular}{|c|c|}
\hline Title No. & Description \\
\hline $\mathbf{5 1 1 . 5 5}$ & Business supplies, data transmission, equipment, software and maintenance \\
\hline $\mathbf{5 1 8 . 5 5}$ & Renting of hardware, equipment, machines and software \\
\hline $\mathbf{5 2 5 . 5 5}$ & Training \\
\hline $\mathbf{5 3 2 . 5 5}$ & Purchased IT services and orders \\
\hline $\mathbf{8 1 2 . 5 5}$ & Purchase of IT hardware, equipment and software \\
\hline
\end{tabular}

In 2013 the Federal Ministry of Finance introduced a restructuring of the Federal Budget which affects the accounting of IT expenses among others. The reform 
breaks up the structure of the title group mentioned above providing that the individual budget of a department must by default include the titles "purchased IT services and orders" (532.01) and "purchase of IT hardware, equipment and software" (812.02). IT spending which cannot be assigned to one of these titles has to be included in more general administration titles like for instance "renting and leasing" (518.01) or "training" (525.01).

Depending on the tasks of a department, there may be additional titles related to IT spending. For example the Federal Ministry of the Interior is responsible for the IT and network policy in Germany. Thus, its budget contains some special titles related to IT, e.g. "Setup and maintenance of the federal data network and other central IT infrastructure" (812.13).

In order to calculate the federal IT spending correctly, we must therefore separately assess the budget of every single federal department not only taking account of its general spending on IT equipment but also of potential IT expenses that derive from its tasks.

For this purpose, the website www.bundeshaushalt-info.de is a useful tool. It gives us aggregate statistics on income and spending of the federal state divided into the three clusters "groups" (income and spending by economic type), "individual households" (income and spending by department and special households) and "functions" (income and spending by assignment/policy area). In combination with the detailed individual households it is possible to obtain an estimation of the federal spending on IT, where the estimation error stems from the lack of transparency of the more general administration titles that contain IT spending among others. For example, with the restructuring of the federal budget, there is no separate title for "Renting of hardware and software" (518.55) since this title is now part of general "Renting and leasing" (518.01). To analyse the contribution of IT to "Renting and leasing" it would be necessary to request further information or to estimate the share of IT spending.

In order to emphasize this difficulty, we take a look on a concrete calculation. In its annual report, the Federal Audit Office (Bundesrechnungshof) publishes information on income and spending of federal institutions. ${ }^{47}$ For 2013 and 2014, the total planned IT spending of the Federal Audit Office itself and the Federal Examination Offices (Prüfämter des Bundes) is given by $€ 4.4$ million and $€ 4.7$ million respectively. Since the Federal Audit Office adapted the new regulations on accounting for IT spending in 2014, we have two different sets of budget titles related to IT at our disposal to replicate these numbers. For 2013, IT spending was still accounted by titles of group 55. The numbers are given as follows:

\footnotetext{
${ }^{47}$ The annual reports can be downloaded from https://www.bundesrechnungshof.de/de/veroeffentlichungen/bemerkungenjahresberichte/jahresberichte/berichte-2000-2014
} 
Table 19: IT spending of the Federal Audit Office and Federal Examination Offices 2013 by titles in thousands of $€$

\begin{tabular}{|l|l|}
\hline Title & Spending \\
\hline $\begin{array}{l}511.55 \text { - Business supplies, data transmission, equipment, software and } \\
\text { maintenance }\end{array}$ & $782+771=1,553$ \\
\hline 518.55 - Renting of hardware, equipment, machines and software & $150+25=150$ \\
\hline 525.55 - Training & $250+80=330$ \\
\hline 532.55 - Purchased IT services and orders & $325+289=614$ \\
\hline 812.55 - Purchase of IT hardware, equipment and software & $935+820=1,805$ \\
\hline TOTAL & 4,424 \\
\hline
\end{tabular}

For 2014, on the other hand the IT specific group 55 was dismissed so that IT spending is not separated from non-IT related administrative spending anymore in titles 511.01, 518.01 and 525.01:

Table 20: IT spending of the Federal Audit Office and Federal Examination Offices 2014 by titles in thousands of $€$

\begin{tabular}{|l|l|}
\hline Title & Spending \\
\hline $\begin{array}{l}511.01 \text { - Business supplies, data transmission, equipment, software and } \\
\text { maintenance (including non-IT) }\end{array}$ & $1,276+1,080=2,356$ \\
\hline $\begin{array}{l}518.01 \text { - Renting of hardware, equipment, machines and software } \\
\text { (including non-IT equipment and machines) }\end{array}$ & $506+0=506$ \\
\hline 525.01 - Training (including non-IT) & $500+430=930$ \\
\hline 532.01 - Purchased IT services and orders & $362+274=636$ \\
\hline 812.02 - Purchase of IT hardware, equipment and software & $764+1,094=1,858$ \\
\hline TOTAL & 6,286 \\
\hline
\end{tabular}

As can be seen, with the old accounting system we are able to obtain the exact amount of IT spending with the publicly accessible data given in the single budgets while the embedment of IT spending in general administrative titles leads to a sum that overestimates IT spending.

The accounting of IT spending at the federal level is probably characteristic of other areas of spending and reveals the difficulty to separate intangible investment out of the data. Still for purchased assets the necessary information (e.g. industry of the supplier) has normally to be collected within government. So a more detailed accounting of intangible investment is not impossible in principle, but there may be too little practical interest so far to implement it.

\subsection{IT Spending and IT Investment at the Federal Level $\mathbf{2 0 1 0}$}

To compare the magnitude, classification and composition of the federal IT budget to the anti-crisis programme, we manually collected data from www.bundeshaushaltinfo.de for individual federal offices for the year 2010 and computed the sum. Table 21 gives an overview of spending per title and of the estimated investment share. 
Table 21: IT spending and estimated IT investment (in thousands of €)

\begin{tabular}{|c|c|c|c|c|}
\hline Title No. & Description & $\begin{array}{l}\text { Total Federal } \\
\text { Government }\end{array}$ & $\begin{array}{c}\text { Estimated } \\
\text { investment low }\end{array}$ & $\begin{array}{c}\text { Estimated } \\
\text { investment high }\end{array}$ \\
\hline 511.55 & $\begin{array}{l}\text { Business supplies, data } \\
\text { transmission, equipment, } \\
\text { software and maintenance }\end{array}$ & 230,466 & 46,093 & 115,233 \\
\hline 518.55 & $\begin{array}{l}\text { Renting } \\
\text { equipment, } \\
\text { software }\end{array}$ & 34,803 & 0 & 0 \\
\hline 525.55 & Training & 26,024 & 26,024 & 26,024 \\
\hline 532.55 & $\begin{array}{l}\begin{array}{l}\text { Purchased } \\
\text { orders }\end{array} \\
\text { IT services and }\end{array}$ & 221,022 & 44,204 & 110,511 \\
\hline \multirow{4}{*}{812.55} & $\begin{array}{l}\text { Purchase of IT hardware, } \\
\text { equipment and software }\end{array}$ & 248,875 & 248,875 & 248,875 \\
\hline & software only & 155,570 & 155,570 & 155,570 \\
\hline & hardware only & 82,345 & 82,345 & 82,345 \\
\hline & $\begin{array}{l}\text { Specific titles to policy areas } \\
\text { that are related to IT }\end{array}$ & $1,252,714$ & 626,357 & 876,900 \\
\hline \multicolumn{2}{|c|}{ Total Spending } & $2,013,904$ & 991,554 & $1,377,543$ \\
\hline \multicolumn{2}{|c|}{$\begin{array}{l}\text { Estimated share of intangibles in the } \\
\text { non-specific investment }\end{array}$} & & $51.1 \%$ & $57.4 \%$ \\
\hline \multicolumn{2}{|c|}{$\begin{array}{l}\text { Share of software in the non-specific } \\
\text { intangible investment }\end{array}$} & & $56.5 \%$ & $48.7 \%$ \\
\hline \multicolumn{2}{|c|}{$\begin{array}{l}\text { Share of training in the non-specific } \\
\text { intangible investment }\end{array}$} & & $13.95 \%$ & $9.05 \%$ \\
\hline
\end{tabular}

We assumed that the titles "training" (525.55) and "purchases of hardware and software" (812.55) represent entirely investment expenditures. The title 518.55 for renting does not represent investment expenditure. Since we do not have further information of the content of the titles "business supplies" (511.55) and "purchased IT services" (532.55), but guess that they contain some investment expenditure, e.g., for equipment or for IT consulting, we worked with two alternative assumptions. A low investment share in these titles is assumed to be 20 percent and a high investment share 50 percent.

In addition to the regular titles, IT spending is listed under specific titles for policy areas that are related to IT. In the year 2010, this concerns the Ministries of the Interior, Economic Affairs and Energy, Defence as well as Education and Research. Some of these titles are related to projects of the anti-crisis programme, e.g. the project "federal networks" is included in the title "development and operation of the federal network" (812.01) which belongs to the budget of the Ministry of the Interior. This spending on particular policy areas accounts for 62 percent of total spending. Since we lack detailed information on most of these projects, we assume that alternatively 50 or 70 of the corresponding budget were invested in tangible or intangible assets. 
For some titles like training we know that investment was intangible. Other categories are mixed. Since the specific expenditure for policy areas, of which we do not have more detailed quantitative information, makes up more than half of the total expenditure, we do not attempt to estimate the share of intangibles in total investment. Within the non-specific spending, we estimate intangible investment to amount to 50 to 60 percent.

\subsection{Comparison with the Results from the Anti-Crisis Programme}

The total IT spending in 2010 at the federal in level that could be traced from budget data is around 2 billion. We estimate that between 1 and 1.4 billion of it corresponds to investment. Between 600 and 900 million of it was invested into specific projects of particular ministries. Thus the additional 500 million invested in federal IT by the stimulus package over three years roughly corresponds to the annual regular IT spending at the federal level (excluding specific policy areas, for which there is also some overlap with the anti-crisis programme). Compared to regular expenditure, the size of the anti-crisis programme is thus considerable.

Our approximated numbers for the regular expenditure that is not related to particular policy areas point to a share of intangible investment of 50 to 60 percent. Additional IT-related intangibles are probably created by own-account expenditure within government, e.g., by IT professionals. Compared with the intangible share in the anticrisis programme displayed in Table 13, the share in regular budget is of similar size (the difference is in our view too small to be interpreted given the quite strong assumptions we need to make to compute shares at all.). The result shows that the creation of IT-related intangibles makes up an important share of IT spending at the federal level. Information on federal budget spending is insufficient to identify all particular categories.

Within regular expenditure, the only categories of intangibles that could be easily identified were software and training. After 2013, the identification of training also becomes more difficult, because IT training is not accounted separately from other training. The share of software in total intangible investment (excluding specific policy areas) is estimated at 49 to 57 percent. The share of training is estimated at 9 and 14 percent. In this we count as software half of the sum classified as investment from title 511.01. The other half is counted as hardware. Compared with results from Table 14 on the IT investment programme, we find here a similar share of software (46 percent in the programme) and a higher share of training ( 2 percent in the programme).

\section{Conclusion}

Summarizing the main quantitative insights, we have seen that half of the investment within the German anti-crisis programme at the level of the federal IT went into improving IT security. According to our estimations, a bit more than half of the investment was intangible. Nearly half of the intangible investment went into software, a quarter into consulting. Own-account investment associated with the 
measures is, however, missing from the numbers and may have a higher share of creation of organisational structures and training. Within the pillar IT security, nearly half of the spending was on consulting, within the pillar IT organisation, 37 percent was spent on organisational structures. Databases made up a surprisingly low share of 2 percent of the spending that we are able to categorise. Another 5 percent, however, were invested in other categories, such as software, to support the creation of databases.

Our research shows that the classification of intangibles by Corrado, Hulten and Sichel (2005) can be applied via key word search to the anti-crisis programme and proves a very useful framework for classification of project-level data in the public sector. In contrast to budget data, project-level data more frequently allow the identification of outputs rather than inputs of intangible investment. Unfortunately some further quantitative information collected on the projects in an evaluation study did not become available to us.

Since the anti-crisis programme was not a research programme but aimed rather at the practical implementation of new infrastructure and processes, intellectual property was mainly created in practical development and implementation. Thus we identified the category of "concepts" as the relevant category for intellectual property in our context. This may inspire also other research on intangibles in contexts were intellectual property output beyond patents can be observed. Some "concepts" may also be created in the context of organisational capital.

When compared at the international level with regard to IT spending, the German stimulus package "Konjunkturpaket II" 2009-2011 had a comparatively low focus on broadband. Compared with the US, budget for modernizing IT at the federal level was relatively high and the societal goals to be promoted by this (e.g. Green IT) were formulated in an explicit way. US investment was more concentrated on the technical performance of the infrastructure, e.g., a high amount was spent on building up a new data centre. Both programmes share a strong focus on IT security. The publically available records of the US programme contain industry classifications for the goods and services purchased. Such records could greatly facilitate the analysis of assets created and it might be helpful to include them also in future project data to be collected in Germany. Given the strong assumptions that had to be made for imputation and the different forms of information available, a detailed quantitative comparison between the US and Germany did not seem advisable at this stage.

The size of the anti-crisis programme with 500 million Euro is considerable when compared to an annual IT investment at the federal level of 1 to 1.4 billion Euro in 2010. Though we can only gauge the share of intangibles in the regular budget, our numbers indicate that it could be one half or higher, with software in turn amounting to half of the intangibles. Thus our research shows that IT-related intangibles other than software make up an important part of public investment at the federal level in Germany. One way to better classify this investment, at least in the case of purchased goods and services, would be to better record the goods and services 
purchased by the state using the classifications concordant with national accounts. While this information should be available at the aggregate level for government, it is not available for IT-related intangibles or for the Federal Government only. The administrative burden of such a procedure may be too high for regular budget. But in the case of special programmes like stimulus packages this could greatly facilitate the assessment of the project impact beyond direct employment effects in the firms that received orders from the programme.

Finally, we present an exercise to give some idea about the measurement of the capital created by the investment programme, where we try to gauge the value of the intangible part of the capital stock created by it five years later.

Following Corrado et al. (2012), we assume a stochastic discard function that is thought to determine the "probability that a given asset type will survive in productive use from one period to the next". The interaction of a decay function, needed to account for the asset's productivity in the course of time on the condition that it survives, with a discard function having a high early failure rate, results in a very high rate of geometric depreciation $\delta$ which is also known as economic depreciation. We stick to the terms used in the paper and define $\bar{T}$ to be an estimate of an asset's service life. The parameter $d$ is defined as the "declining balance rate" which reflects the convexity of the age-price profile of the asset.

$$
\delta=d / \bar{T}
$$

Equation (1) specifies that for a given $\bar{T}$ higher rates of $d$ imply a higher rate of economic depreciation. By using the INTAN-Invest depreciation rates presented in the paper we get an idea of the current value of the programme's intangible investment. We use equation (2) presented in Baldwin et al. (2005) to calculate the depreciation amount:

$$
D_{i}=\delta(1-\delta)^{i} \quad \forall i=1, \ldots, T
$$

Due to the very fast geometric depreciation, the overall value of intangible investment decreases from $€ 235,201,858$ to only $€ 8,569,228$ within the course of five years. This leaves room for further thought on both research on rates of decay applied to intangibles and the long-run effects of the anti-crisis programme on knowledge assets.

A further important methodological issue associated with the assessment of public intangible investment and the resulting capital services is the specification of its rate of return (see Mas, 2015).

In their paper laying out fundamental principles and problems associated with accounting for intangibles in the public sector within the SPINTAN project, Corrado et al. (2015) write: "While we do not wish to overstate what fiscal policy can deliver on any score, we do wish to better understand the strength and location of its intangible investment lever." In our paper, we take the example of the German anti-crisis programme to categorize primarily the location of the investment in terms of four 
different areas of investment targeted, two different dimensions of e-government and seven categories of intangible investment. We observe, however, that there is to date little awareness of setting a priori goals with regard to these locations. This would require more systematic monitoring (which may, however, not be possible with the detail applied in this paper) but also more systematic analysis of the strength of effects on economic growth and other socio-economic goals. If we take the example of IT security, which was a high priority in both the German and the US spending programme, it may indeed be difficult to model the optimal relative investment in this area compared to other areas, such as open data, as a function of specific goals. 


\section{List of References}

Agarwal, H., Santos, L. \& Starikova, I. 2014, 'Managing the demand for IT infrastructure', McKinsey on Business Technology, no. 33, pp.30-35. Available from: http://www.mckinsey.com/insights/mckinsey quarterly. [22.11.2016].

Alencar, A. J., Fernandes, R. P, Schmitz, E. A. \& Correa, A. L 2013, 'Maximizing the Appropriation of the Intangible Benefits Yielded by IT Investments in the Public Sector', Journal of Software, vol.08, no. 07, pp. 1537-1549. Available from: http://www.jsoftware.us/vol8/jsw0807-01.pdf. [22.11.2016]

Aizcorbe, A. M., Moylan, C. E. \& Robbins, C. A. 2009, 'BEA Briefing: Toward Better Measurement of Innovation and Intangibles', Survey of Current Business, vol. 89, pp. 10-23. Available from:

http://www.bea.gov/scb/pdf/2009/01\%20January/0109 innovation.pdf. [22.11.2016].

Baldwin, J., Gellatly, G., Tanguay, M. \& Patry, A. 2005, 'Estimating Depreciation Rates for the Productivity Accounts', Paper presented at the OECD Workshop on Productivity Measurement, Madrid, ES.

Baldwin, J.R., Gu, W. \& Macdonald, R. 2012, 'Intangible Capital and Productivity Growth in Canada', The Canadian Productivity Review, Statistics Canada Catalogue no. 15-206-X, no. 29. Available from: http://www.statcan.gc.ca/pub/15-206-x/15-206x2012029-eng.htm. [22.11.2016]

Barabas, G., Döhrn, R. \& Gebhardt, H. 2011, 'Was brachte das Konjunkturpaket II?', Wirtschaftsdienst, vol. 91, no.07, pp. 496-498.

Bunget, O. C., Blidisel, R. G., Fleaga, L. \& Popa, I. E. 2014, 'Empirical Study of Intangible Assets in Romanian Municipalities', E + M Economics and Management, vol. 17, no. 03, pp. 136-151. Available from: http://www.ekonomie-

management.cz/en/archiv/search/detail/1200-empirical-study-of-intangible-assets-inromanian-municipalities/.

Corrado, C., Hulten, C. \& Sichel, D. 2005, 'Measuring Capital and Technology: An Expanded Framework' in Measuring Capital in the New Economy, eds. C. Corrado, J. Haltiwanger \& D. Sichel, University of Chigaco Press, pp. 11-46.

Corrado, C., Hulten, C. \& Sichel, D. 2009, 'Intangible Capital and U.S. Economic Growth', Review of Income and Wealth, vol. 55, no. 03, pp. 661-685.

Corrado, C., Haskel, J., Jona-Lasinio, C., \& Iommi, M. 2012, 'Intangible Capital and Growth in Advanced Economies: Measurement Methods and Comparative Results'. INTAN Invest Working Paper. Available from:

http://www.intan-invest.net/. [22.11.2016].

Corrado, C., Haskel, J., Jona-Lasinio, C. \& Iommi, M. 2013, 'Innovation and intangible investment in Europe, Japan, and the United States', Oxford Review of Economic Policy, vol. 29, no. 02, pp. 261-286.

Corrado, C., Haskel, J., Jona-Lasinio, C., Iommi, M. \& O'Mahony, M. 2014, 'Public and Private Sector Intangible Investments in the European Economies: Preliminary Results from the SPINTAN Project". Paper prepared for the IARIW $33^{\text {rd }}$ General Conference, Rotterdam, NL.

Corrado, C., Haskel, J.\& Jona-Lasinio, C. 2015, 'Public Intangibles: The Public Sector and Economic Growth in the SNA'. SPINTAN Working Paper, no. 01. 
Available from:

http://www.spintan.net/wp-content/uploads/public/WP 01 Corrado et al.pdf. [22.11.2016]

Dwivedi, Y.K. 2011, 'Adoption, Usage, and Global Impact of Broadband Technologies: Diffusion, Practice and Policy'. Information Science Reference, New York.

Fernandes, R. P., Alencar, A. J., Schmitz, E. A. \& Correa, A. L. 2014, 'Analysing IT Investments in the Public Sector: A Project Portfolio Approach', Journal of Software, vol. 09, no. 07, pp. 1687-1700. Available from: http://www.jsoftware.us/show-82-9821.html. [22.11.2016]

Fernandes, M. C., Alencar, A. J., Schmitz, E. A., da Silva, M. F.\& Fernandes, R. P. 2015, 'Acknowledging the Effect of the Depreciation of Tangible and Intangible Benefits upon the Evaluation of E-Gov Projects', Journal of Software, vol. 10, no. 07, pp. 842-868. Available from:

http://www.jsoftware.us/index.php?m=content\&c=index\&a=show\&catid=154\&id=2353 [22.11.2016].

IEEE Standard Glossary of Software Engineering Terminology, IEEE Std 610.121990, Standards IEEE.

Jarboe, K. P. 2013, 'Federal Investments in Intangibles. A Look at the President's FY 2014 Budget', Athena Alliance Working Paper No. 09.

Lev, B. \& Radhakrishnan, S. 2005, 'The Valuation of Organizational Capital' in Measuring Capital in the New Economy, eds. C. Corrado, J. Haltiwanger \& D. Sichel, University Chicago Press, pp. 73-110.

Leibinger, B., Müller, R. \& Wiesner, H. 2008, 'Öffentliche Finanzwirtschaft', $12^{\text {th }}$ edn, Hüthig-Jehle-Rehm, pp. 70-72, Heidelberg.

Lucke, J. \& Reinerman, H. 2000, 'Speyerer Definition von Electronic Government', Forschungsinstitut für öffentliche Verwaltung, Online Publication. Available from: http://192.124.238.248/ruvii/SP-EGov.pdf. [22.11.2016].

Nakamura, L. 2001, 'What is the U.S. Gross Investment in Intangibles? (At Least) One Trillion Dollars a Year!' Federal Reserve Bank of Philadelphia Working Paper No. 01-15.

OECD 2009, 'Policy Responses to the Economic Crisis: Investing in Innovation for Long-Term Growth'.

Oulasvirta, L. 2012, 'The reluctance of a developed country to choose International Public Sector Accounting Standards of the IFAC. A critical case study', Critical Perspectives on Accounting, vol. 25, no. 03, pp. 271-285. Available from: http://www.sciencedirect.com/science/article/pii/S1045235412001347. [22.11.2016].

Parker, R. P. \& Grimm, B. T. 2000, 'Recognition of Business and Government Expenditures for Software as Investments: Methodology and Quantitative Impacts, 1958-1998', Bureau of Economic Analysis Paper prepared for the meeting of the BEA Advisory Committee. Available from: http://bea.gov/papers/index.htm. [22.11.2016].

Peleg, S. 2008, 'Service Lives of Research and Development, United Nations. 
Piekkola, H. 2011, 'Intangible Capital - Driver of Growth in Europe', Proceedings of the University of Vaasa, Reports 167. Available from:

http://www.innodrive.org/attachments/File/Intangible Capital Driver of Growth in E urope Piekkola(ed).pdf. [22.11.2016].

Powell, T.C. \& Dent-Micallef, A. 1997, 'Information Technology as Competitive Advantage: The Role of Human, Business, and Technology Resources', Strategic Management Journal, vol. 18, no. 05, pp. 375-405. Available from:

http://www.jstor.org/stable/3088167?seq=1\#page scan tab contents. [22.11.2016].

Projektgruppe BundOnline, 2005, Definition E-government, BundOnline. Available from:

http://www.lueneburg.de/Portaldata/1/Resources/lklg dateien/lklg dokumente/verwal tungsleitung/01 buero landrat/Definitionen E-Government.pdf. [22.11.2016].

Rajlich, V. 2011, Software Engineering: The Current Practice, 1st edn, Chapman \& Hall/CRC Innovations in Software Engineering and Software Development Series, p. 24, Boca Raton, FL.

Software Investment Guide, Oracle Technology Global Price List June 2015.

Available from: http://www.oracle.com/us/corporate/pricing/technology-price-list070617.pdf. [22.11.2016].

Szkuta, K., Pizzicannella, R. \& Osimo, D. 2014, 'Collaborative approaches to public sector innovation: A scoping study', Telecommunications Policy, vol. 38, no. 05, pp. 558-567. Available from:

http://www.sciencedirect.com/science/article/pii/S0308596114000615. [22.11.2016]

United Nations, European Commission, International Monetary Fund, Organisation for Economic Co-operation and Development, World Bank, 2009, System of National Accounts 2008, United Nations Publication Sales No. E.08.XVII.29. Available from: http://unstats.un.org/unsd/nationalaccount/docs/SNA2008.pdf.

Statista, 2014, Survey of civil servants and judges. Available from: http://de.statista.com/statistik/daten/studie/37096/umfrage/beamte-und-richter-indeutschland/. [22.11.2016]

van Ark, B, Hao, J X., Corrado, C. \& Hulten, C. 2009, 'Measuring intangible capital and its contribution to economic growth in Europe', EIB Papers, vol. 14, no. 01, pp. 62-93. Available from:

https://www.econstor.eu/handle/10419/44905. [22.11.2016]. 


\section{List of Sources for the Database}

\section{Project-related sources}

AdminStudio, computer software 2015. Available from:

http://www.flexerasoftware.com/enterprise/products/application-

packaging/adminstudiol. [22.11.2016].

Adobe, creative software 2015. Available from:

http://www.adobe.com/de/downloads.html.[22.11.2016].

Deutscher Bundestag, 2010, 'Entwurf eines Gesetzes über die Feststellung des Bundeshaushaltsplans für das Haushaltsjahr 2011 (Haushaltsgesetz 2011)', Die Bundeskanzlerin. Available from:

http://dip21.bundestag.de/dip21/btd/17/025/1702500.pdf. [22.11.2016].

Firefox, computer software 2015. Available from: https://www.mozilla.org/enUS/firefox/newl. [25.08.2015].

GS-Tool, computer software 2008. Available from:

https://www.bsi.bund.de/DE/Themen/ITGrundschutz/GSTOOL/Download/download node.html. [22.11.2016].

IT-Investitionsprogramm, 2012, 'Übersicht der zugesagten Finanzmittel im Rahmen des IT-Investitionspgroamms - beendete Maßnahmen', Die Beauftragte der Bundesregierung für Informationstechnik. Available from: http://www.cio.bund.de/SharedDocs/Publikationen/DE/StrategischeThemen/liste beendete massnahmen download.pdf;jsessionid=A7196F58C1F6D7A 65A7A32FECB3549F6.2 cid334? blob=publicationFile. [22.11.2016].

IT-Investitionsprogramm, 'Übersicht über die Maßnahmen des ITInvestitionsprogramms', Die Beauftragte der Bundesregierung für Informationstechnik. Available from:

http://www.cio.bund.de/SharedDocs/Publikationen/DE/Bundesbeauftragte-fuerInformationstechnik/IT Rat Beschluesse/beschluss 832012 anlage 1 download.p df? blob=publicationFile. [21.04.2015].

Kameralis, computer software 2012. Available from: http://www.kameralis.de/produkt.html. [22.11.2016].

Kaspersky, security software 2015. Available from: http://www.kaspersky.com/. [22.11.2016].

Linux, computer software. Available from: http://www.linux.com/. [22.11.2016].

Windows10, computer software 2015. Available from: http://www.microsoft.com/dede/windows/. [22.11.2016].

YaCy, Available from: http://yacy.de/de/index.html. [22.11.2016]. 


\section{Project Sources}

A1\#1: IT-Investitionsprogramm im Rahmen des Pakts für Beschäftigung und Stabilität in Deutschland, Beschluss Nr. 16/2009, Anlage 03. Available from: http://www.cio.bund.de/Web/DE/Politische-Aufgaben/IT-

Rat/Beschluesse/Tabelleninhalte/beschluss 16 2009.html?nn=4623828. [22.11.2016].

A1\#1: Krempl, S. 2010, 'Bundesregierung setzt verstärkt auf KryptoHandys', heiseSecurity. Available from:

http://www.heise.de/security/meldung/Bundesregierung-setzt-verstaerkt-auf-KryptoHandys-962342.html. [22.11.2016].

A1\#1: Deutscher Bundestag, 2009, Drucksache 16/13831. Available from: http://dipbt.bundestag.de/dip21/btd/16/138/1613831.pdf. [22.11.2016].

A1\#1: Deutscher Bundestag 2010, Drucksache 17/1072. Available from: http://dip21.bundestag.de/dip21/btd/17/010/1701072.pdf [22.11.2016].

A1\#2: IT-Investitionsprogramm im Rahmen des Pakts für Beschäftigung und Stabilität in Deutschland, Beschluss Nr. 16/2009, Anlage 04. Available from http://www.cio.bund.de/Web/DE/Politische-Aufgaben/IT-

Rat/Beschluesse/Tabelleninhalte/beschluss 16 2009.html?nn=4623828. [22.11.2016].

A1\#3: IT-Investitionsprogramm im Rahmen des Pakts für Beschäftigung und Stabilität in Deutschland, Beschluss Nr. 16/2009, Anlage 07. Available from: http://www.cio.bund.de/Web/DE/Politische-Aufgaben/IT-

Rat/Beschluesse/Tabelleninhalte/beschluss 16 2009.html?nn=4623828. [22.11.2016].

A1\#3: Intelligent Solutions for the Highest IT Security Demands. Available from: https://www.fox-it.com/nl/files/2012/05/SINA Brochure.pdf. [22.11.2016].

A2\#1: Bundesministerium des Innern, Bericht der Bundesregierung zur 'Gesamtstrategie IT- Netze der öffentlichen Verwaltung'. Available from: https://netzpolitik.org/wp-upload/2013-03-18 Gesamtstrategie-IT-Netze-deroeffentlichen-Verwaltung.pdf. [22.11.2016].

A2\#1: IT-Investitionsprogramm im Rahmen des Pakts für Beschäftigung und Stabilität in Deutschland, Beschluss Nr. 16/2009, Anlage 08. Available from: http://www.cio.bund.de/Web/DE/Politische-Aufgaben/IT-

Rat/Beschluesse/Tabelleninhalte/beschluss 16 2009.html?nn=4623828. [22.11.2016].

A2\#1: Bundesministerium des Innern, 2013, Bericht der Bundesregierung zur „Gesamtstrategie IT-Netze der öffentlichen Verwaltung. Available from: https://netzpolitik.org/wp-upload/2013-03-18 Gesamtstrategie-IT-Netze-deroeffentlichen-Verwaltung.pdf. [22.11.2016].

A2\#2: Der Beauftragte der Bundesregierung für Informationstechnik, ITInvestitionsprogramm im Rahmen des Pakts für Beschäftigung und Stabilität in Deutschland, 19.02.2009. Available from:

http://www.cio.bund.de/SharedDocs/Publikationen/DE/Bundesbeauftragter-fuerInformationstechnik/IT Rat Beschluesse/beschluss 162009 anlage 9 download.p df? blob=publicationFile. [22.11.2016]. 
A2 \#2: IT-Investitionsprogramm im Rahmen des Pakts für Beschäftigung und Stabilität in Deutschland, Beschluss Nr. 16/2009, Anlage 09. Available from: http://www.cio.bund.de/Web/DE/Politische-Aufgaben/IT-

Rat/Beschluesse/Tabelleninhalte/beschluss 16 2009.html?nn=4623828. [22.11.2016].

A2\#3: IT-Investitionsprogramm im Rahmen des Pakts für Beschäftigung und Stabilität in Deutschland, Beschluss Nr. 16/2009, Anlage 10. Available from: http://www.cio.bund.de/Web/DE/Politische-Aufgaben/IT-

Rat/Beschluesse/Tabelleninhalte/beschluss 16 2009.html?nn=4623828. [22.11.2016].

A2\#3: DNS Security Extensions, Securing the Domain Name System, DNSSEC. Available from: http://www.dnssec.net/. [22.11.2016].

A2\#4: Bundesministerium des Innern, Bericht der Bundesregierung zur 'Gesamtstrategie IT- Netze der öffentlichen Verwaltung'. Available from: https://netzpolitik.org/wp-upload/2013-03-18 Gesamtstrategie-IT-Netze-deroeffentlichen-Verwaltung.pdf. [22.11.2016].

A2\#4: Informationsverbund Berlin-Bonn (IVBB), 2011, Der Beauftragte der Bundesregierung für Informationstechnik. Available from: http://www.cio.bund.de/Web/DE/Strategische-Themen/ModerneVerwaltungskommunikation/IVBB/ivbb inhalt.html. [22.11.2016].

A2\#4: Das Projekt "Netze des Bundes" (NdB), Der Beauftragte der Bundesregierung für Informationstechnik. Available from: http://www.cio.bund.de/Web/DE/Strategische-Themen/Moderne-

Verwaltungskommunikation/Netze des Bundes/netze des bundes node.html;jsessi onid=3396A489A5C6DF18327E0390BCE4D6D3.2 cid297. [22.11.2016].

A2\#4: Informationsverbund der Bundesverwaltung (IVBV), Der Beauftragte der Bundesregierung für Informationstechnik. Available from: http://www.cio.bund.de/Web/DE/Strategische-Themen/ModerneVerwaltungskommunikation/IVBV/ivbv node.html. [22.11.2016].

A3\#1 \& A3\#2: IT-Investitionsprogramm im Rahmen des Pakts für Beschäftigung und Stabilität in Deutschland, Beschluss Nr. 16/2009, Anlage 15. Available from: http://www.cio.bund.de/Web/DE/Politische-Aufgaben/IT-

Rat/Beschluesse/Tabelleninhalte/beschluss 16 2009.html?nn=4623828. [22.11.2016].

A4\#1: Informationen, Kosten, Hintergründe der neue Ausweis. Available from: http://www.ausweis-app.com/kostenlos-it-sicherheitskit/. [22.11.2016].

A4\#1: IT-Investitionsprogramm im Rahmen des Pakts für Beschäftigung und Stabilität in Deutschland, IT-Sicherheitskit: Übersicht der Maßnahmen; Der Beauftragte der Bundesregierung für Informationstechnik. Available from: http://www.cio.bund.de/SharedDocs/Publikationen/DE/StrategischeThemen/it sicherheitskit massnahmen download.pdf? blob=publicationFile. [22.11.2016].

A4\#1: IT-Sicherheitskit für Bürgerinnen und Bürger, 2011, Der Beauftragte der Bundesregierung für Informationstechnik. Available from: http://www.cio.bund.de/Web/DE/Strategische-Themen/IT- 
Investitionsprogramm/Massnahmen/massnahmen it sicherheitskit inhalt.html. [22.11.2016]

A5\#1: IP Telefon verschlüsseln, SecurStar. Available from: http://www.securstar.de/ip-telefon-verschluesseln.html. [22.11.2016].

A5\#3: Schallbruch, M. 2009, 'Informationssysteme als Kritische Infrastrukturen in Deutschland', Presentation IT-Direktor im Bundesministeriums des Innern. Available from: https://www.cducsu.de/sites/default/files/090506-BMI.pdf. [22.11.2016].

A5\#14 \& A5\#15: Bundesministerium des Innern, Umsetzungsplan KRITIS des Nationalen Plans zum Schutz der Informationsinfrastrukturen. Available from: http://www.bmi.bund.de/SharedDocs/Downloads/DE/Broschueren/2007/Kritis.pdf? blob=publicationFile. [22.11.2016].

A5\#16: Bundesamt für Sicherheit in der Informationstechnik, 2007, BSI-Leitfaden Bedrohung der Informationssicherheit durch den gezielten Einsatz von

Schadprogrammen. Available from: http://www.computerundrecht.de/BSI3.pdf. [22.11.2016].

A5\#16: Bundesamt für Sicherheit in der Informationstechnik, Remote-Controlled Browsers System (ReCoBS). Available from:

https://www.bsi.bund.de/SharedDocs/Downloads/DE/BSI/Internetsicherheit/recobslan ginfo pdf.pdf? blob=publicationFile. [22.11.2016].

A5\#19: Informationssicherheit durch ISO/IEC 27001, Tüv-Süd. Available from: http://www.tuev-sued.de/management-systeme/it-dienstleistungen/iso-27001. [22.11.2016].

A5\#26: Bundesanstalt für den Digitalfunk der Behörden und Organisationen mit Sicherheitsaufgaben, Digitalfunk BOS. Available from:

http://www.bdbos.bund.de/DE/Digitalfunk BOS/digitalfunk bos node.html. [22.11.2016].

A5\#29: Bundesverwaltungsamt, Nationales Waffenregister (NWR). Available from:

http://www.bva.bund.de/DE/Themen/Sicherheit/NationalesWaffenregister/nationales waffenregister-node.html. [22.11.2016].

A5\#30: M 6.33 Entwicklung eines Datensicherungskonzepts, Bundesamt für Sicherheit in der Informationstechnik. Available from:

https://www.bsi.bund.de/DE/Themen/ITGrundschutz/ITGrundschutzKataloge/Inhalt/ content $/ \mathrm{m} / \mathrm{m06} / \mathrm{m06033.html.} \mathrm{[22.11.2016].}$

A5\#32: SINA Workstation, Secunet. Available from:

http://www.secunet.com/en/topics-solutions/high-security/sina/sina-workstation/. [22.11.2016].

A5\#33: Identitätsdokument für die reale und die digitale Welt, Bundesdruckerei. Available from: https://www.bundesdruckerei.de/de/94-neuer-personalausweis. [22.11.2016].

A5\#33: Dermalog, Fingerprint Live Scanner ZF1. Available from: http://www.dermalog.com/pdf/ZF1 Einzelseiten.pdf. [22.11.2016].

A5\#41: European Chemical Agency, 2014, 'REACH-IT Industry, User Manual'. Available from: 
https://echa.europa.eu/documents/10162/22308542/discover reach it en.pdf/b0632 da6-c7ab-49a5-86c1-761246e75424. . [22.11.2016].

A5\#41: Sicherheitsmechanismen in elektronischen Ausweisdokumenten, Bundesamt für Sicherheit in der Informationstechnik. Available from:

https://www.bsi.bund.de/DE/Themen/DigitaleGesellschaft/ElektronischeAusweise/Sic herheitsmechanismen/sicherheitsmechanismen node.html. [22.11.2016].

A5\#42: M 6.93 Notfallvorsorge für z/OS-Systeme, Bundesamt für Sicherheit in der Informationstechnik. Available from:

https://www.bsi.bund.de/DE/Themen/ITGrundschutz/ITGrundschutzKataloge/Inhalt/ content/m/m06/m06093.html. [22.11.2016].

A5\#49: Sicherheitsinfrastruktur PKI (public key infrastructure), ITWissen. Available from: http://www.itwissen.info/definition/lexikon/Sicherheitsinfrastruktur-PKI-publickey-infrastructure.html. [22.11.2016].

A5\#50: Aktive und passive Netzwerkkomponenten., net.curity InformationsTechnologien $\mathrm{GmbH}$. Available from: http://www.netcurity.de/netzwerkund-betreuung/aktive-und-passive-netzwerkkomponenten.html. [22.11.2016].

A5\#53: Integrated Data Processing, System Components Library. Available from: https://www.idp.net/sysinfo/networking.asp. [22.11.2016].

A5\#54: Becker, F. 2011, 'GSTOOL 5.0 - Der Aufstand', Bundesanstalt für Landwirtschaft und Ernährung. Available from:

https://www.bsi.bund.de/SharedDocs/Downloads/DE/BSI/Veranstaltungen/Grundsch utz/3GS Tag 2011/Der-Aufstand-Becker.pdf? blob=publicationFile. [22.11.2016].

A5\#55: Microsoft, 2000, 'Step-by-Step Guide to the Microsoft Management Console'. Available from: https://msdn.microsoft.com/en-us/library/bb742442.aspx.

[22.11.2016].

A5\#55: Microsoft, What is a firewall?, Safety \& Security Center. Available from: https://www.microsoft.com/en-us/safety/pc-security/firewalls-whatis.aspx.

[22.11.2016].

A5\#58: Bundesamt für Sicherheit in der Informationstechnik, Durchführungskonzept für Penetrationstests Sicherheit. Available from:

https://www.bsi.bund.de/SharedDocs/Downloads/DE/BSI/Publikationen/Studien/Pene trationstest/penetrationstest pdf.pdf? blob=publicationFile. [22.11.2016].

A5\#59: Mehr Möglichkeiten im Netzwerk zum Vorteil Ihres Unternehmens, Hewlett-

Packard. Available from: http://www8.hp.com/de/de/software-

solutions/asset/software-asset-

viewer.html?asset $=944277 \&$ module $=1640633 \&$ docname=4AA1-

6185ENW\&page=1639762. [22.11.2016].

A5\#60: McAfee Network Security Platform, McAfee: Available from:

http://www.mcafee.com/us/resources/data-sheets/ds-network-security-platform-nsseries.pdf. [22.11.2016].

A5\#60: Next Generation Intrusion Prevention System (NGIPS), Cisco. Available from: http://www.cisco.com/c/en/us/products/security/ngips/index.html. [22.11.2016].

A5\#60: Scarfone, K., Mell, P. 2007, 'Guide to Intrusion Detection and Prevention Systems (IDPS)', National Institute of Standards and Technology, Special Publication 800-94. 
Available from: http://nvlpubs.nist.gov/nistpubs/Legacy/SP/nistspecialpublication80094.pdf. [22.11.2016].

A5\#64: MySecurityPoint - das Awarenessportal für Informationssicherheit, ditis. Available from: https://www.ditis.de/infosec/mysecuritypoint.php. [22.11.2016].

A5\#66: Citrix Access Gateway, Citrix. Available from:

http://www.syntaxinc.com/Downloads/Citrix/AppSec/Access\%20Gateway\%20Feature S\%200verview.pdf. [22.11.2016].

A5\#66: Citrix Access Gateway Specifications Sheet, Citrix. Available from:

https://www.citrix.com/content/dam/citrix/en us/documents/downloads/netscaleraccess-gateway/Citrix Access Gateway Spec Sheet.pdf. [22.11.2016].

A5\#67: Cisco ASA Firewallsysteme, Liwicom. Available from:

http://www.liwicom.at/firewallsysteme. [22.11.2016].

A5\#81: Genugate, 'High Resistance Firewall für hochsichere Netzübergänge'.

Available from: https://www.genua.de/fileadmin/download/produkte/genugatebroschuere.pdf. [22.11.2016].

A5\#85: Öffentlicher Dienst/Verwaltung, 'Die IBM Musterinstallation zur Integration von Bund Online-Basiskomponenten'. Available from:

ftp://public.dhe.ibm.com/software/emea/de/lotus/BOL low.pdf. [22.11.2016].

A5\#85: Die Virtuelle Poststelle; Bundesamt für Sicherheit in der Informationstechnik. Available from:

https://www.bsi.bund.de/DE/Themen/DigitaleGesellschaft/EGovernment/VirtuellePost stelle/virtuellepoststelle node.html. [22.11.2016].

A5\#105: Operis Analysis Kit; Operis. Available from:

http://www.operisanalysiskit.com/. [22.11.2016].

A5\#105: IS-Revision, Bundesamt für Sicherheit in der Informationstechnik. Available from: https://www.bsi.bund.de/DE/Themen/Cyber-

Sicherheit/Dienstleistungen/ISRevision/isrevision node.html. [22.11.2016].

A5\#108: SINA-Systembeschreibung, Bundesamt für Sicherheit in der

Informationstechnik. Available from:

https://www.bsi.bund.de/DE/Themen/Kryptotechnologie/SINA/Systembeschreibung/s ystembeschreibung node.html. [22.11.2016].

A5\#115: DOMEA eMail-Archiv, Open Text. Available from:

http://www.opentext.de/was-wir-tun/produkte/domea/optionale-produkte/domeaemail-archiv. [22.11.2016].

B1\#1: IT-Investitionsprogramm im Rahmen des Pakts für Beschäftigung und Stabilität in Deutschland, Beschluss Nr. 16/2009, Anlage 19. Available from: http://www.cio.bund.de/Web/DE/Politische-Aufgaben/IT-

Rat/Beschluesse/Tabelleninhalte/beschluss 16 2009.html?nn=4623828. [22.11.2016].

B1\#2: IT-Investitionsprogramm im Rahmen des Pakts für Beschäftigung und Stabilität in Deutschland, Beschluss Nr. 16/2009, Anlage 20. Available from: http://www.cio.bund.de/Web/DE/Politische-Aufgaben/IT-Rat/Beschluesse/Tabelleninhalte/beschluss 16 2009.html?nn=4623828. [22.11.2016]. 
B3\#1: Das ZIVIT als DLZ-IT des Bundes, Zentrum für Informationsverarbeitung und Informationstechnik. Available from: http://www.zivit.de/DE/Ueberuns/DLZIT/DLZ\%20IT node.html. [02.06.2015].

B3\#2: ITS-Handbuch: Virtuelle Desktop-Umgebung, Universität Kassel. Available from: http://www.uni-kassel.de/its-handbuch/computerarbeitsplaetze/virtuelledesktops.html. [22.11.2016].

B3\#3: Bundesnetzagentur. Available from:

http://www.bundesnetzagentur.de/cln 1431/DE/Home/home node.html. [22.11.2016].

B3\#5: Repositorium des BMEL, Julius Kühn-Institut. Available from: http://www.jki.bund.de/de/startseite/ueber-das-jki/infozentrum-undbibliothek/projekte.html. [04.06.2015].

B3\#9: Register Factory, Bundesverwaltungsamt. Available from: http://www.bva.bund.de/DE/Organisation/Abteilungen/Abteilung BIT/Leistungen/IT P rodukte/RegisterFactory/node.html. [22.11.2016].

B3\#10: Willkommen bei der e-Vergabe. Available from: https://www.evergabeonline.de/start.html;jsessionid=1053A73463A53E123D49273CACE79B33?0. [22.11.2016].

B3\#11: Mach®. Available from: https://www.mach.del. [22.11.2016].

B3\#11: Die individuelle Beratung, Mach. Available from: https://www.mach.de/loesungen/beratung/. [22.11.2016].

B3\#12: Bundesministerium der Finanzen, Bundesministerium des Innern, Bundesministerium für Verkehr, Bau und Stadtentwicklung, Bundesministerium der Verteidigung \& Bundesministerium für Wirtschaft und Technologie, 2009, 'Regierungsprogramm "Zukunftsorientierte Verwaltung durch Innovationen"'. Available from: http://www.verwaltung-

innovativ.de/SharedDocs/Publikationen/Presse Archiv/projekt dlz zwischenbericht. pdf? blob=publicationFile\&v=1. [22.11.2016].

B3\#12: Lohman, M. B. 2009, Bundesministerium des Innern, 'Ausbau von Dienstleistungszentren (DLZ) im BMI und seinen GB-Behörden'. Available from: http://www.effizienterstaat.eu/Fruehere-Kongresse/Kongress2009/binarywriterservlet?imgUid=5032f6b2-d912-031a-69a53327b988f2ee\&uBasVariant=11111111-1111-1111-1111-111111111111. [22.11.2016].

B3\#12: Das Projekt DLZ, Die Bundesregierung. Available from: http://www.verwaltunginnovativ.de/DE/Organisation/ProjektDLZ/projekt dlz node.html. [22.11.2016].

B3\#12: Bundesministerium des Innern \& Bundesministerium der Finanzenministerium, 'Die neuen Dienstleistungszentren Available from: https://www.bmi.bund.de/SharedDocs/Downloads/DE/Broschueren/2008/Die neuen Dienstleistungszentren.pdf? blob=publicationFile. [22.11.2016].

B3\#12: Bundesministerium der Finanzen, Bundesministerium des Innern, Bundesministerium für Verkehr, Bau und Stadtentwicklung, Bundesministerium der Verteidigung \& Bundesministerium für Wirtschaft und Technologie, 2010, 'DLZProjekt, Projektbericht 2010 - 'Zukunftsorientierte Verwaltung durch Innovationen'. 
Available from: http://www.verwaltung-

innovativ.de/SharedDocs/Publikationen/Presse Archiv/projekt dlz projektbericht $p$ hase 3.pdf? blob=publicationFile\&v=1. [22.11.2016].

B3\#12: Bundesministerium des Innern, Projekt DLZ, Projektsteckbriefe, 16.04.2009. Available from: http://www.verwaltung-

innovativ.de/SharedDocs/Publikationen/Presse Archiv/projekt dlz projektsteckbrief e.pdf? blob=publicationFile\&v=1. [22.11.2016].

B3\#13: Bundesverwaltungsamt, Das Dienstleistungszentrum des

Bundesverwaltungsamtes. Available from:

http://www.bva.bund.de/DE/Ueberblick/DLZ/dlz node.html. [22.11.2016].

B3\#16: Bundesamt für Sicherheit in der Informationstechnik, Sicherheitsspezifische Basisfunktionalitäten für konsolidierte DLZ-IT, Sicherheit Service-orientierter Architekturen am Beispiel modernen E-Governments. Available from: https://www.bsi.bund.de/SharedDocs/Downloads/DE/BSI/SOA/DLZ-ITSecurity.pdf? blob=publicationFile. [22.11.2016].

B3\#19: Bundesverwaltungsamt, Der zentrale Dienstleister des Bundes Führungskräfte-Forum des Behördenspiegels, Gestaltung der Aufgabenerweiterung im BVA, 2509.2014. Available from: http://www.fuehrungskraefte-forum.de/wpcontent/uploads/2014/09/Verenkotte.pdf. [29.06.2015].

B3\#21: Modern data warehouse, Microsoft. Available from:

https://www.microsoft.com/en-gb/sql-server/data-warehouse-big-data. [22.11.2016]

B3\#34: Bundesanstalt für Wasserbau DLZ Informationstechnik im Geschäftsbereich des BMVBS, 'Gehörlos im Intranet'.

B3\#36: Aris Cloud Overview, What is ARIS. Available from: http://www.ariscloud.com/ARISCloud.htm. [22.11.2016]

B3\#38: Webopedia, application server. Available from: http://www.webopedia.com/TERM/A/application server.html. [22.11.2016]

C1 \#1: Green IT-Initiative des Bundes, der Beauftragte der Bundesregierung für Informationstechnik. Available from: http://www.cio.bund.de/Web/DE/InnovativeVorhaben/Green-IT/green it node.html. [22.11.2016].

C1 \#1: Beschluss des Rates der IT-Beauftragten, Beschluss Nr. 08/2008, Rat der ITBeauftragten. Available from: http://www.cio.bund.de/Web/DE/Politische-

Aufgaben/IT-

Rat/Beschluesse/Tabelleninhalte/beschluss 08 2008.html?nn=4623828. [22.11.2016].

C1 \#1: IT-Investitionsprogramm im Rahmen des Pakts für Beschäftigung und Stabilität in Deutschland, Beschluss Nr. 16/2009, Anlage 11. Available from: http://www.cio.bund.de/Web/DE/Politische-Aufgaben/IT-

Rat/Beschluesse/Tabelleninhalte/beschluss 16 2009.html?nn=4623828. [22.11.2016].

C1 \#1: IT-Investitionsprogramm im Rahmen des Pakts für Beschäftigung und Stabilität in Deutschland, Beschluss Nr. 16/2009, Anlage 12. Available from: http://www.cio.bund.de/Web/DE/Politische-Aufgaben/IT-

Rat/Beschluesse/Tabelleninhalte/beschluss 16 2009.html?nn=4623828. [22.11.2016]. 
C1 \#1: Beschluss des Rates der IT-Beauftragten, Beschluss Nr. 20/2009, Rat der ITBeauftragten. Available from: http://www.cio.bund.de/Web/DE/Politische-

Aufgaben/IT-Rat/Beschluesse/Tabelleninhalte/beschluss 20 2009.html?nn=4623828. [22.11.2016].

C2 \#4: Cisco TelePresence TX9000 Series, Data Sheet. Available from:

http://www.cisco.com/c/en/us/products/collaboration-endpoints/telepresence-tx9000series/index.html. [22.11.2016].

C2 \#4: Cisco Tele Presence. Available from:

http://www.cisco.com/web/DE/telepresence/index.html. [22.11.2016].

C2 \#6: HP 3PAR Thin Provisioning Software. Available from:

http://www8.hp.com/us/en/products/storage-software/product-

detail.html?oid=5044622. [22.11.2016].

C2 \#19: Storage Area Networks, Storage World. Available from:

http://www.forbiddenhistory.co.uk/storageworld/tech/san/overview.htm. [22.11.2016].

C2 \#22: Hintemann, R. 2008, 'Blade-Server. Technologie, Einsatzgebiete und Betriebskonzepte', BITKOM: Available from:

https://www.bitkom.org/Publikationen/2008/Leitfaden/Blade Server/080523 Blade S erver.pdf. [22.11.2016].

C2 \#22 \& C2 \#52: Lenovo BladeCenter, Lenovo. Available from:

http://shop.lenovo.com/us/en/systems/servers/blades/bladecenter/. [22.11.2016].

C2 \#48: Cisco TelePresence MCU 4505, Cisco. Available from:

http://www.cisco.com/c/en/us/support/conferencing/telepresence-mcu-

4505/model.html. [22.11.2016].

C2 \#48: Tandberg Codec 3000, 6000 MXP, Reference Guide for system integrations, Tandberg. Available from:

http://www.cisco.com/c/dam/en/us/td/docs/telepresence/endpoint/mxp-

series/f8/api reference guide/tandberg mxp reference user guide for system inte grators f8.pdf. [22.11.2016].

C2 \#49: AGFEAO AS 281 All-In-One - Product Description, AGFEO. Available from: https://www.agfeo.de/agfeo web/hp3.nsf/start.xsp?c=1512\&az1=prod\&az2=prod. [22.11.2016].

C2 \#54: Löbmann, M. 2011,'10 Schritte zur RZ-Konsolidierung', Computerwoche. Available from: http://www.computerwoche.de/a/10-schritte-zur-rzkonsolidierung,2362811. [22.11.2016].

C2 \#71: IP Office Application Server 9.0 Installation and Maintenance, Avaya. Available from: https://downloads.avaya.com/css/P8/documents/100174011. [22.11.2016].

C2 \#82: VMware ESX and VMware ESXi. The Market Leading Production-Proven Hypervisors, Vmware. Available from: http://www.vmware.com/de/products/esxi-andesx.html. [14.06.2015].

D1\#1, D1 \#2, D1 \#3, D1 \#4 \& D1 \#5 : IT-Investitionsprogramm im Rahmen des Pakts für Beschäftigung und Stabilität in Deutschland, Beschluss Nr. 16/2009, Anlage 21. Available from:

http://www.cio.bund.de/Web/DE/Politische-Aufgaben/IT-Rat/Beschluesse/Tabelleninhalte/beschluss 16 2009.html?nn=4623828. [22.11.2016]. 
D1\#2: ISO/IEC 2382:2015(en), Information technology Vocabulary, Online Browsing Platform (OBP). Available from:

https://www.iso.org/obp/ui/\#iso:std:iso-iec:2382:ed-1:v1:en. [22.11.2016].

D1\#3: BSI TR-03112 Das eCard-API-Framework, Bundesamt für Sicherheit in der Informationstechnik,. Available from:

https://www.bsi.bund.de/DE/Publikationen/TechnischeRichtlinien/tr03112/index htm. html. [22.11.2016].

D1\#5: Der Personalausweis. Bundesministerium des Innern. Available from: https://www.personalausweisportal.de/DE/Service/Kontakt/kontakt node.html. [22.11.2016].

D2\#1, D2\#4, D2\#6, D2 \#7 \& D2\#8: IT-Investitionsprogramm im Rahmen des Pakts für Beschäftigung und Stabilität in Deutschland, Beschluss Nr. 16/2009, Anlage 18. Available from: http://www.cio.bund.de/Web/DE/Politische-Aufgaben/ITRat/Beschluesse/Tabelleninhalte/beschluss 16 2009.html?nn=4623828. [22.11.2016].

D2\#2: Was ist SharePoint?, Microsoft. Available from: https://support.office.com/deat/article/Was-ist-SharePoint-97b915e6-651b-43b2-827d-fb25777f446f. [22.11.2016].

D2\#9: Bundesamt für Kartographie und Geodäsie. Available from: http://www.geoportal.de/DE/GDI-DE/gdi-de.html?lang=de. [22.11.2016].

D2\#10: GDI-DE Testsuite, Geodateninfrastruktur Deutschland Koordinierungsstelle. Available from: http://testsuite.gdi-de.org/gdi/. [22.11.2016].

D2\#11: Interoperable Bohrdaten im bundesweiten Geodatenportal, BGR. Available from:

http://www.bgr.bund.de/DE/Themen/Geodatenmanagement/Projekte/abgeschlossen/ interoperable-bohrdaten.html. [26.06.2015].

D3\#1: FIZ Karlsruhe — Leibniz-Institut für Informationsinfrastruktur, Deutsche Digitale Bibliothek. Available from:

https://www.deutsche-digitale-bibliothek.de/content/ueber-uns/fiz-karlsruhe-leibnizinstitut-fur-informationsinfrastruktur. [22.11.2016].

D3\#2: Die Beratungsleistungen des Bundesverwaltungsamtes, Bundesverwaltungsamt. Available from:

http://www.bva.bund.de/DE/Ueberblick/BPB/bpb node.html. [22.11.2016].

D3\#3: Stellenangebote, Bund DE Verwaltung Online. Available from:

http://www.bund.de/Content/DE/Stellen/Suche/Formular.html?view=processForm\&nn =4641482. [22.11.2016].

D3\#4: Fachinformationsführer Sport, Bundesinstitut für Sportwissenschaft. Available from: www.sport-if.de/fisport/LuceneQuery. [22.11.2016].

D3\#5: Max und Flecke Helferland, Bundesamt für Bevölkerungsschutz und Katastrophenhilfe. Available from:

http://www.bbk.bund.de/SubSites/KI/DE/Home/home node.html;jsessionid=F10E37D 9E3E01EE805587ED8944B4BB4.1 cid345. [22.11.2016].

D3\#10: Leitfaden Beratung bei Diskriminierung, Erste Schritte und Weitervermittlung, Antidiskriminierungsstelle des Bundes. Available from: 
http://www.antidiskriminierungsstelle.de/SharedDocs/Downloads/DE/publikationen/Le itfaden Verweisberatung 20121109.pdf? blob=publicationFile. [22.11.2016].

D3\#11: Wegweiser-Dement, Bundesministerium für Familie, Senioren, Frauen und Jugend. Available from: http://www.wegweiser-demenz.de/startseite.html. [22.11.2016].

D3\#12: Kinder Ministerium, Bundesministerium für Familie, Senioren, Frauen und Jugend. Available from: http://www.kinder-ministerium.de/startseite/. [22.11.2016].

D3\#13: Perspektive Wiedereinstieg, Bundesministerium für Familie, Senioren, Frauen und Jugend. Available from: http://www.perspektivewiedereinstieg.de/Navigation/DE/startseite node.html;isessionid=44D76D1AD55CB6 FAA7484443342DADDA: [22.11.2016].

D3\#14: Surfen:Ohne:Risiko, Bundesministeriums für Familie, Senioren, Frauen und Jugend. Available from: http://www.surfen-ohne-risiko.net/.[22.11.2016].

D3\#15: Wiedereinstiegsrechner, Bundesministerium für Familie, Senioren, Frauen und Jugend. Available from: http://www.wiedereinstiegsrechner.de/. [22.11.2016].

D3\#16: Antidiskriminierungstelle des Bundes. Available from: http://www.antidiskriminierungsstelle.de/DE/Home/home node.html. [22.11.2016].

D4\#1: Abschlussbericht zu P23R veröffentlicht, Prozess-Daten-Beschleuniger, p23r. Available from: http://www.p23r.del. [22.1.2016].

D4\#1: Bundesministerium des Innern, P23R Prozess Daten Beschleuniger. Available from: http://www.bmi.bund.de/DE/Themen/IT-Netzpolitik/E-Government/P23R/p23rnode.html. [22.11.2016].

D4\#2: Bundesministerium des Innern, Koordinierungsprojekt 'Nationale Prozessbibliothek'. Available from: http://www.itplanungsrat.de/SharedDocs/Downloads/DE/Entscheidungen/12. Sitzung/Sachstand sbericht\%20NPB.pdf? blob=publicationFile. [18.07.2015].

D4\#2: Nationale Prozessbibliothek. Available from:

http://www.prozessbibliothek.de/index.php/Projektziel.html. [13.07.2015].

D4\#3: Beschaffungsamt des Bundesministeriums des Innern, Umsetzung mit UMM UN/CEFACT. Available from: http://www.verwaltung-

innovativ.de/SharedDocs/Publikationen/Artikel/faltblatt $x$ vergabe.pdf? blob=public ationFile\&v=2. [22.11.2016

D4\#3: Das Projekt XVergabe, XVergabe. Available from:

https://www.xvergabe.org/confluence/display/xv/Home. [22.11.2016].

D4\#5: XPolizei, XÖV-Vorhaben. Available from:

https://www.xrepository.de/Inhalt/urn:uuid:ae6cdb0c-47b7-45bb-8616b92cce4f10bc.xhtml. [22.11.2016].

D4\#5: XPolizei, Aufbau eines einheitlichen Repository für polizeilich relevante Kerndatenobjekte. Availabe from:

http://www.xoev.de/detail.php?gsid=bremen83.c.11268.de. [22.11.2016].

D4\#6: XWaffe, XÖV-Vorhaben. Available from:

https://www.xrepository.de/Inhalt/urn:uuid:ae519e88-82c1-4219-8c0a-

99dd1a3af561.xhtml. [22.11.2016] 
D4\#6: XWaffe, Der Standard. Available from: https://www.nwr-fl.de/Seiten/xwaffekataloge.aspx. [22.11.2016].

D4\#6: 24.03.2010, Deutschland-Online Vorhaben 'Nationales Waffenregister', Informationsveranstaltung Nationales Waffenregister. Available from:

http://www.it-planungsrat.de/SharedDocs/Downloads/DE/Pressemitteilung/Folienvortrag\%20NWR\%20-\%20M\%C3\%A4rz\%202010.pdf? blob=publicationFile. [06.07.2015].

D4\#7: XVergabe, AG Bekanntmachung Spezifikation Version 2.0 - 00. Available from:8

https://www.xvergabe.org/confluence/download/attachments/1703974/20111010++xvergabe+ag+bekanntmachung+-+spezifikation+v2+-

+ dokumentation+v008. pdf? version=1\&modificationDate=1318608169919.

[22.11.2016].

D4\#8: Willkommen bei eSTATISTIK.core. Available from:

https://core.estatistik.de/core/. [22.11.2016].

D4\#9: Vehicle crime initiatives, Interpol. Available from: http://www.interpol.int/Crimeareas/Vehicle-crime/Vehicle-crime-initiatives. [22.11.2016].

D4\#10: PowerPoint KdB-Schulung, Kaufhaus des Bundes. Available from: http://www.kdb.bund.de/KdB/DE/Service/Schulung/Dokumentation/PowerPoint KdB Schulung.html. [22.11.2016].

D4\#10: Produktsortiment, Kaufhaus des Bundes. Available from:

http://www.kdb.bund.de/KdB/DE/Produktsortiment/node.html;jsessionid=33E4F609B 547B94B2A6F57741D0ABA2C.1 cid380. [22.11.2016].

D4\#10: Verwaltung macht Spass, MACH MARKTPLATZ. Available from:

https://www.mach.de/mach-marktplatz.html?file=tl files/01-MACH/03-PDF/01-

Produktblaetter/01-Finanzen/MACH Markplatz.pdf. [25.07.2015].

D4\#11: Was ist Easy PASS?, Bundespolizei. Available from:

http://www.easypass.de/EasyPass/DE/Was ist EasyPass/home node.html.

[22.11.2016].

D4\#14: Justizportal des Bundes und der Länder, E-Justice-Dienste und

Informationsangebote. Available from: http://www.justiz.de/index.php. [22.11.2016].

D4\#16: The African portal of agriculture, e.rails. Available from:

http://www.erails.net/. [22.11.2016]

D4\#17: MACH Informationmanager, MACH MARKTPLATZ. Available from:

https://www.mach.de/loesungen/software/ecm/informationmanagerl. [22.11.2016].

D4\#19: Zentrale Vergabe im Geschäftsbereich des Bundesministerium für Ernährung, Landwirtschaft und Verbraucherschutz, Bundesanstalt für Landwirtschaft und Ernährung. Available from:

http://www.ble.de/SharedDocs/Downloads/06 Dienstleistungen/01 ZentraleVergabe stelle/BroschuereZV.pdf? blob=publicationFile. [22.11.2016].

D4 \#21: E-PRTR, The European Pollutant Release and Transfer Register. Available from: http://prtr.ec.europa.eul. [22.11.2016]. 
D4 \#26: Helpdesk reach-clp-biozid, Nationale Auskunfstelle REACH, CLP und Biozide. Available from: http://www.reach-clp-biozid-helpdesk.de/de/Startseite.html. [22.11.2016].

D4 \#29: Fraunhofer \& TMF, 2011, 'Elektronische Patientenakte gemäß § 291a SGB V'. Available from: https://www.sit.fraunhofer.de/fileadmin/dokumente/infomaterial/deutsch/DIE PATIENTENAKTE IN DER VERSORGUNG.pdf. [22.11.2016].

D4 \#32: Bundesministerium des Innern, 'Organisationskonzept elektronische Verwaltungsarbeit'. Available from: http://www.verwaltunginnovativ.de/SharedDocs/Publikationen/Organisation/e vorgangsbearbeitung.pdf? blob=publicationFile. [22.11.2016].

D4 \#33: DLR, 'Handlungshilfe zur Nutzung des Elektronischen Antrags- und Angebotssystems easy-Online', version 1.7.0.0. Available from: http://www3.unibonn.de/forschung/forschungsdezernat/7.1-foerderberatung/bmbfbundesmittel/anleitung-easy. [22.11.2016].

D4 \#33: easy-Online, Die Bundesregierung. Available from: https://foerderportal.bund.de/easyonline/. [22.11.2016].

D4 \#35: EMF - Datenportal für Landesbehörden, Kommunen und Gemeinden, Bundesnetzagentur. Available from: https://datenportal.bundesnetzagentur.de/. [22.11.2016].

D4 \#35: Zugang zum Energiedaten-Portal der Bundesnetzagentur, Bundesnetzagentur. Available from: https://app.bundesnetzagentur.de/Energie/. [22.11.2016].

D4 \#38: Firmenmanager, 'Der AI FIRMENMANAGER'. Available from: http://www.aiag.de/wp-content/uploads/sites/7/2015/03/Firmenmanager.pdf. [22.11.2016].

D4 \#40: Röh, C. 2013, 'Strategische Implikationen der luK-Technik' in IuK-Technik und internationale Unternehmensführung: Kommunikation - Koordination Konfiguration', edn 2003, Springer, p. 192.

D4 \#44: Oschatz, B., Rosenkranz, J., Arzt, S., Steuerlein, A. 2014, 'Kosten energierelevanter Bau- und technischer Anlagenteile bei der energetischen Sanierung von Nichtwohngebäuden/Bundesliegenschaften', BBSR-OnlinePublikation Nr. 06/2014, Bundesinstitut für Bau-, Stadt- und Raumforschung. Available from:

http://www.bbsr.bund.de/BBSR/DE/Veroeffentlichungen/BBSROnline/2014/DL ON06 2014.pdf? blob=publicationFile\&v=4. [22.11.2016].

D4 \#45: Hitabis, Referenzprofil eVKE. Available from:

https://www.hitabis.de/media/BBR eVKE 1.pdf. [22.11.2016].

D5 \#4: GOsa² Project, GOsa². Available from: https://oss.gonicus.de/labs/gosa/. [22.11.2016].

D5 \#4: Fujitsu, 'Datenblatt Fujitsu FUTRO S720 Thin Client'. Available from: http://sp.ts.fujitsu.com/dmsp/Publications/public/ds-futro-s720-de.pdf. [22.11.2016].

D5 \#5: Erfahrungsberichte Bundespolizei, Bundesverwaltungsamt. Available from: http://www.bva.bund.de/DE/Organisation/Abteilungen/Abteilung BIT/Leistungen/IT B eratungsleistungen/CCOSS/04 Erfahrungsberichte/inhalt.html?docld=4482364\&notF irst=true. [20.07.2015]. 
D5 \#8: XRepository - XÖV-Vorhaben, XRepository. Available from:

https://www.xrepository.de/index.xhtml. [22.11.2016].

D5 \#10: GDV Geo Software, GDV. Available from:

http://www.gdv.com/gdv/technologien/java-gis/java-gis-

referenzen/bundesnetzagentur.html. [22.11.2016].

D5 \#13: Dithard, D. 2003, 'Squid', dpunkt.verlag GmbH. Available from:

http://www.squid-handbuch.de/hb/. [22.11.2016].

D5 \#13: What is a Web Proxy, WhatlsMyIP. Available from:

https://www.whatismyip.com/what-is-a-web-proxyl. [22.11.2016].

D5 \#14: Gemeinschaft zur Förderung der privaten deutschen Pflanzenzüchtung e.V. \& Julius Kühn-Institut, 2011, 'Nationales Evaluierungsprogramm pflanzengenetischer Ressourcen bei Getreide - EVA II'. Available from: https://www.juliuskuehn.de/media/Veroeffentlichungen/Flyer/EVA.pdf. [22.11.2016].

D5 \#14: Informationssystem für Evaluierungsdaten pflanzengenetischer Ressourcen, Julius Kühn-Institut. Available from: http://eva2.jki.bund.de/portal/public/classic/. [21.07.2015].

D5 \#15: TYPO3, TYPO3. Available from: https://typo3.orgl. [22.11.2016].

D5 \#16: 4.9 Lösungen GSTOOL 4.7, Bundesamt für Sicherheit in der Informationstechnik. Available from:

https://www.bsi.bund.de/DE/Themen/ITGrundschutz/ITGrundschutzSchulung/Webkur SGSTOOL47/03 Administration/04 DatenbankenKonfigurieren/09 testloesungen/tes tloesungen node.html. [22.11.2016].

D5 \#17: YaCy, YaCy. Available from: http://yacy.de/del. [22.11.2016]. 